RESEARCH

\title{
The Genexpress Index: A Resource for Gene Discovery and the Genic Map of the Human Genome
}

\author{
Rémi Houlgatte, ${ }^{1,2,3,}$ Régine Mariage-Samson, ${ }^{1,2,3}$ Simone Duprat, ${ }^{2}$ \\ Anne Tessier, ${ }^{2}$ Simone Bentolila, ${ }^{1,2}$ Bernard Lamy, ${ }^{2}$ and \\ Charles Auffray ${ }^{1,2,4}$
}

${ }^{1}$ Genexpress, Centre National de la Recherche Scientifique (CNRS) UPR420, 94801 Villejuif CEDEX, France; ${ }^{2}$ Genexpress, Généthon, 91002 Evry CEDEX, France

Detailed analysis of a set of 18,698 sequences derived from both ends of 10,979 human skeletal muscle and brain cDNA clones defined 6676 functional families, characterized by their sequence signatures over 5750 distinct human gene transcripts. About half of these genes have been assigned to specific chromosomes utilizing 2733 eSTS markers, the polymerase chain reaction, and DNA from human-rodent somatic cell hybrids. Sequence and clone clustering and a functional classification together with comprehensive data base searches and annotations made it possible to develop extensive sequence and map cross-indexes, define electronic expression profiles, identify a new set of overlapping genes, and provide numerous new candidate genes for human pathologies.

During the last 20 years, since the first descriptions of eucaryotic cDNA cloning (Rougeon et al. 1975; Efstratiadis et al. 1976), cDNA studies have played a central role in molecular genetics. Early attempts to systematically analyze gene transcript repertoires were limited by available technologies (Milner and Sutcliffe 1983; Putney et al. 1983; Palazzolo et al. 1987; Sutcliffe 1988; Kato 1990), a situation that changed in the mid eighties with the development of fluorescent-based DNA sequencing (Smith et al. 1985, 1986). The initial proposal (Brenner 1990) and demonstrations of the potential of systematic sequencing and mapping of cDNA clones (Adams et al. 1991; Höög 1991; Hyde et al. 1991; Okubo et al. 1991; Wilcox et al. 1991) were soon followed by numerous medium- to large-scale cDNA sequencing studies in a variety of tissues and species in both animals and plants (Adams et al. 1992, 1993a,b; Gieser and Swaroop 1992; Khan et al. 1992; McCombie et al. 1992; Okubo et al. 1992, 1994; Uchimiya et al. 1992, 1994; Waterston et al. 1992; Höfte et al. 1993; Matsubara and Okubo

\footnotetext{
${ }^{3}$ The first two authors contributed equally to this work. ${ }^{4}$ Corresponing author.

E-MAIL remi@pauline.vjf.inserm.fr; FAX (33)(1)49 583509. The complete data contained in Appendices 1 and 2 can be found in electronic form at http://www.cshl.org/.
}

1993; Park et al. 1993; Takeda et al. 1993; Affara et al. 1994; Davies et al. 1994; Kerr et al. 1994; Konishi et al. 1994; Kurata et al. 1994; Liew et al. 1994; Murakawa et al. 1994; Newman et al. 1994; Nishiguchi et al. 1994; Nomura et al. 1994; Sasaki et al. 1994; Soares et al. 1994; Sudo et al. 1994; Auffray et al. 1995; Berry et al. 1995; Franco et al. 1995; Frigerio et al. 1995; Pawlak et al. 1995). This developing field has been recognized as an important component of the Human Genome Project for gene discovery (Collins and Galas 1993) and has been the subject of several reviews (Kato 1992; Southern 1992; Grausz and Auffray 1993; Matsubara and Okubo 1993; Sikela and Auffray 1993). Mapping of the corresponding human genes has not developed as rapidly, although it is a limiting step in the identification of disease genes (for review, see Hochgeschwender 1992; Parrish and Nelson 1993; Chen et al. 1994; Collins 1995). Thus, until recently, in addition to the 3700 genes registered in the Genome Data Base, a relatively limited number of gene transcripts characterized by cDNA sequencing have been assigned to a specific chromosome (Wilcox et al. 1991; Durkin et al. 1992; Gieser and Swaroop 1992; Khan et al. 1992; Polymeropoulos et al. 1992, 1993; Fukushima et al. 1994; Murakawa et al. 1994; Berry et al. 1995). 
We have recently reported the basic methodology and primary results of our Integrated Molecular Analysis of the human Genome and its Expression (IMAGE), a strategy to collect sequence signatures from collections of cDNA clones, quantitative hybridization signatures on high-density filters, and chromosomal assignment of the corresponding genes using humanrodent somatic cell hybrids (Auffray et al. 1995). We collected 26,938 sequence signatures from both ends of cDNA clones from a human skeletal muscle and a normalized infant brain (Soares et al. 1994) libraries and developed 2792 eSTS markers (Auffray et al. 1995) that were assigned to specific chromosomes. In this paper we report a detailed description of the various steps of secondary analyses of two-thirds of these sequences, and most of the eSTS markers to index $>5750$ distinct human gene transcripts by sequence clustering and data base comparison. We define electronic expression profiles of the transcripts in the various tissues in which they have been observed and the chromosomal assignments of about half of the corresponding genes. We describe sequencing and mapping crossindexes to facilitate the use of this resource for gene discovery, the construction of the genic map of the human genome, and the identification of disease genes.

\section{SEQUENCE CLUSTERING}

Each sequence was compared with all the others obtained from the same library using the FASTA (Pearson 1990) program. When a sequence had $>90 \%$ similarity over its entire length with a previously registered sequence, it was considered redundant and its analysis was stopped. Other sequences were considered unique and were searched for more limited overlaps by a second round of comparisons. Both processes involved automatic

1 prefiltration and interactive validation steps, which provided links between sequences. Contigs were defined as a set of sequences grouped together by common links rather than multialignments. This made it possible to group sequences that cannot be aligned such as alternatively spliced sequences or sequences with lowquality segments at their ends, when a third sequence was overlapping with both of them (Fig. 1). This was also useful in the case of the brain library, as some cDNA clones appeared to be derived from unspliced mRNA.

A further advantage of this method is that erroneous links based on repeats, composition bias, or highly similar isogenes can be removed when detected at any stage, by inactivating it in the data base without any new calculation. Moreover, as in most cases we have obtained sequences from both ends of the cDNA clones, it was possible to use clone links to group contigs
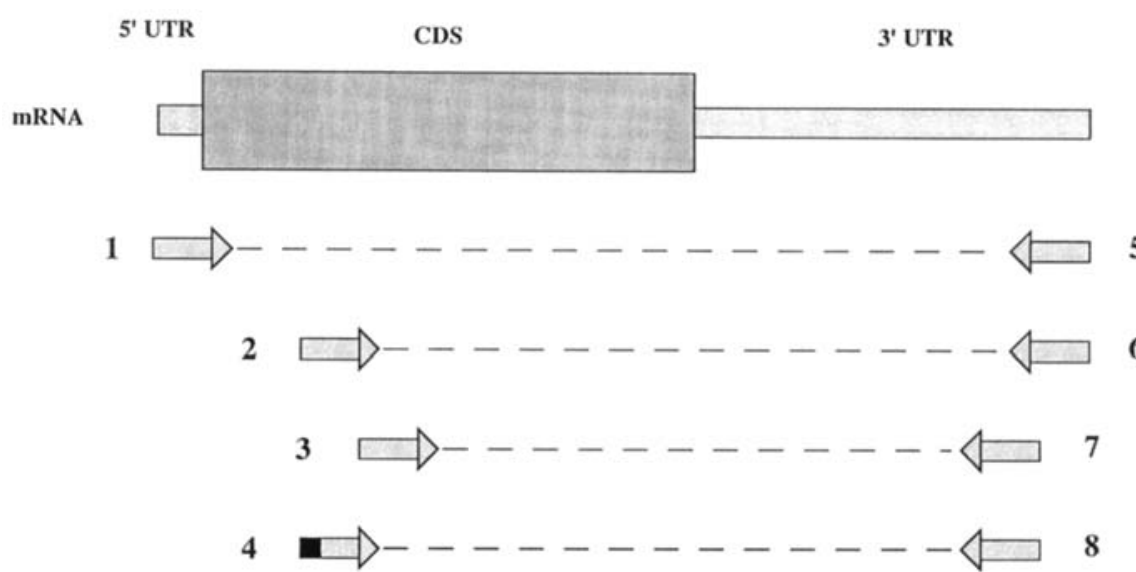

8

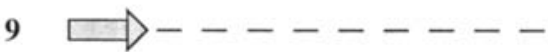

Figure 1 Sequence clustering strategy. Partial sequences (1-9) are represented by arrows, below the mRNA from which they were derived. Broken lines indicate individual clones. Sequence analysis allowed us to find redundant sequences ( $>90 \%$ similar over their entire lengths) such as sequence 6 (identical to sequence 5) or 8 (identical to sequence 7). These redundant sequences were not subject to further analysis. All nonredundant sequences were compared with each other to find overlapping sequences (sequences detected by FASTA, with a Opt parameter $>120,>90 \%$ identities, and validated by users) such as sequences 5 and 7,2 and 3,3 and 4 . This allowed us to cluster sequences into contigs defined as sets of sequences linked either by redundancy or overlaps (sequences 1, 2-4, 5-8, 9) and to cluster together some sequences that could not be aligned (sequences 2 and 4) because of a lowquality segment or alternative splicing (sequence $4 \mathrm{D}$ ), if a third sequence (sequence 3 ) overlapped with them. Sequences derived from the same clone were further clustered into Families (sequences 1-8, 9). After data base comparisons, families defined as Identical or Homolog to the same gene transcript were clustered together (sequences 1-9). 


\section{HOULGATIE EI AL.}

together into families. When applied to the entire set, the 18,698 sequences derived from 10,979 cDNA clones were clustered into 12,713 contigs grouped in 6886 families.

\section{DATA BASE COMPARISONS}

All individual unique sequences were compared with the GenBank nucleic acid sequences (Benson et al. 1994), except the partial cDNA subsection and SWISS-PROT protein sequences (Bairoch and Boeckmann 1994), using the BLAST (Altschul et al. 1990; Gish and States 1993) family of programs to define their level of similarity with known sequences. To avoid spurious similarities resulting from composition bias or repeats, we used a masked version of SWISS-PROT using the XNU (Claverie and States 1993) program. For nucleic acid comparisons, we first compared the sequences with GenBank and a local repeat data base. Repeats detected with a high level of similarity were masked with the XBLAST (Claverie and States 1993) program, and all masked sequences were compared once again with GenBank, to detect similarities that could have been underscored because of the presence of a repeat. All sequences with no significant match $\left(P<10^{-5}\right)$ in any data base were classified as Unknown. To extend the initial matches detected by BLAST, all the other sequences were unmasked and subjected to LFASTA alignment with their nucleic best matches. This was necessary because insertions or deletions that are often present in partial cDNA sequences are not taken into account by BLAST that provides only local uninterrupted alignments, whereas FASTA integrates the presence of gaps. A direct FASTA search would have overcome this problem, but an initial BLAST search directly provides a measurement of the statistical significance of the matches (Altschul et al. 1994).

Sequences were classified as Known if identical to a human sequence, Homolog if highly similar to a vertebrate sequence, Related if having a partial similarity to a sequence of any species, Chimeric if having incoherent matches, or Unknown if no match appeared significant. Sequences from chimeric clones were not studied further. As correct classification depended on the available informations of the hit sequences, such as position of the match or existence of multiple isogenes, we chose to favor human interpretation of all matches with basic principles and no strict rules. For example, a complete but partial similarity with a nonhuman sequence can be more significant than a limited but identical match with a partial human sequence. This could be the case if the human gene has been partially sequenced or if this sequence has been split in different files, whereas the vertebrate homolog is only defined as an mRNA stored in a unique file. Therefore, if only the hit with the best score is taken into account, the identity with a known human sequence will not be detected. Similarly, the detection of $85 \%$ similarity with a vertebrate sequence could lead to classification of the sequence as homologous, but this is erroneous if the human homolog is already described and did not produce a more significant match than with the vertebrate sequence. In that case, the query sequence is probably derived from a related gene, such as an isogene. For all these reasons, a summary of all informations collected including a summary of all the data base matches, FASTA alignment with their nucleic best matches, text extraction of best-match files, six-frame translation, coding frame prediction, nucleic acid, or protein motif predictions was provided to the users for interpretation.

A functional assignment was obtained in most cases, but sometimes it was necessary to perform additional searches, such as multialignments of sequences, data base searches with a limited part of the query sequence, or text searches on data bases, in order to reach the final conclusion. The same functional assignment was derived for clones and families by gathering functional assignment of their constitutive sequences. As different sequences could have similarities with different files of the nucleic acid data base derived from a single gene, it was necessary to create cross-indexes between these files. These cross-indexes were mainly derived from SWISS-PROT cross-indexes, but many additionnal links were derived by comparison of each nucleic acid sequence with the entire GenBank. These cross-indexes link together different nucleic acid sequences derived from a unique gene, but also the encoded protein, as well as the Genome Data Base (GDB) (Fasman et al. 1994) locus or On-line Mendelian Inheritance in Man (OMIM) (Pearson et al. 1994) entries. This also allowed us to establish a special category of link between sequences derived from the same gene but in different organisms. The link of the nucleic acid sequences to SWISS-PROT files made it possible to access annotations of much better quality than those 
available in nucleic acid data bases which are much more limited and sometimes erroneous.

On the other hand, as there are nucleic acid sequences in GenBank that are not yet represented as proteins in SWISS-PROT, this strategy probably failed to detect some matches, because of differences in codon usage in different organisms. It will be possible to take them into account in the future using SWISS-PROT updates or by searching the GenPept nonredundant data base that connects translation of nucleic acid data bases together with protein data base entries.

Partial cDNA sequences were not searched for sequence similarity in the initial process but were searched for overlapping segments as in the clustering process. Tissue origin of the library was extracted to define electronic expression profiles.

\section{TRANSCRIPT ASSIGNMENT}

The cross-indexes allowed us to group different families classified as identical or homologous to the same gene that had not been clustered together by their sequence similarities (Fig. 1). The pool of 1276 such families was reduced by 210 $(16.5 \%)$ during this process, leading to a total of 6676 functional families. This indicates that probably the number of families is an overestimation by $\sim 16.5 \%$ of the number of gene transcripts characterized by partial sequencing. If this coefficient is applied to all families, we can estimate that the 6886 families are probably representative of 5750 different human gene transcripts. The situation appeared to be clearly different in the muscle compared with the brain library. In the muscle library, $24 \%$ of the known or homolog families were lost during the functional clustering step, whereas only $7 \%$ were lost in the brain library. This discrepancy is mainly attributable to the fact that, on average, 1.3 sequences are available for each clone in the muscle library (frequently, the $3^{\prime}$ end sequence was not obtained because of the difficulties of sequencing long poly(A) tails), whereas, on average, 1.8 sequences were available for each clone in the brain library that has relatively short poly(A) tracts by cloning design (Soares et al. 1994). This shows clearly that the gene transcript count can be largely overestimated when $3^{\prime}$ end sequences are not available, as is the case if only 5 ' end sequencing is performed or if the cDNA library is random-primed. Failure to group together different families derived from the same gene transcript in the brain library was attribut- able to the absence of the $3^{\prime}$ end sequence ( $40 \%$ of the cases), alternative splicing (15\%), alternative poly(A) site (33\%), or internal priming of the mRNA (12\%). Conversely, if $3^{\prime}$ sequence is always obtained, gene transcript overestimation should have occured only in $4.3 \%$ of the cases.

Of the 6676 functional families, it can be seen in Table 1 that $12.7 \%$ were already known in man, $3.2 \%$ are human homologs of a gene already known in another vertebrate species, $7.6 \%$ have a partial functional similarity with a known gene, and $76.4 \%$ displayed no significant similarity. Overall, 2515 have been characterized independently at least by partial sequencing. This also indicates that of the 5823 new gene transcripts described in this study, $>4000$ are described for the first time.

\section{COMPARISON BETWEEN SKELETAL MUSCLE AND BRAIN LIBRARIES}

Some differences between the muscle and brain libraries can be observed when comparing the most frequently represented gene transcripts (Table 2). In the muscle library, the 10 most redundant transcripts are derived from already known genes and represent $\sim 20 \%$ of the clones of this library. The most abundant previously uncharacterized transcript in man appears to be derived from a gene mapped to chromosome 2 and related to the Drosophila Kelch protein (rank 13). In the brain library, the situation is completely different, as the most redundant transcript is the human homolog of rat neuronal olfactomedinrelated protein localized in the endoplasmic reticulum and mapped to chromosome 9 and the nine most abundant transcripts are derived from four known, one homolog, and four unknown genes, which together represent only $1.4 \%$ of the library. These differences are in part attributable to variation in gene transcription in these tissues but mostly to the normalization of the brain library. This is also evident from the comparison between the functional classification of the different clones or gene transcripts in the two libraries (Table 3). In the muscle library, the most abundant transcripts encode cytoskeletal elements, metabolic proteins, or transport and storage proteins (functional redundancy of 6.31, 3.40 , and 3.48 , respectively). In the brain library, the most abundant transcripts encode proteins involved in signaling, but global functional redundancy is nearly identical for all the functional classes (ranging from 1.49 to 2.19), and, there- 
HOULGATTE ET AL.

\begin{tabular}{|c|c|c|c|c|}
\hline \multirow{2}{*}{$\begin{array}{l}\text { A } \\
\text { Similiarity }\end{array}$} & \multicolumn{3}{|c|}{ cDNA partial sequences } & \\
\hline & registered & new & total & \\
\hline Identical & 438 & 415 & 853 & \\
\hline Homologous & 104 & 112 & 216 & \\
\hline Related & 165 & 342 & 507 & \\
\hline Unknown & 1393 & 3707 & 5100 & \\
\hline Total & 2100 & 4576 & 6676 & \\
\hline \multirow{2}{*}{$\begin{array}{l}\text { B } \\
\text { Similarity }\end{array}$} & \multicolumn{4}{|c|}{ Gene transcript mapping } \\
\hline & GDB & eSTS & not tested & total \\
\hline Identical & 481 & 101 & 271 & 853 \\
\hline Homologous & 1 & 72 & 143 & 216 \\
\hline Related & 3 & 180 & 324 & 507 \\
\hline Unknown & 24 & 1919 & 3157 & 5100 \\
\hline \multirow[t]{2}{*}{ Total } & 509 & 2272 & 3895 & 6676 \\
\hline & \multicolumn{3}{|c|}{ eSTS markers } & \\
\hline$C$ & identical & partial & different & \\
\hline GDB & $124(80 \%)$ & $10(6 \%)$ & $22(14 \%)$ & \\
\hline Multiple & $325(86 \%)$ & $20(5 \%)$ & $33(9 \%)$ & \\
\hline \multicolumn{5}{|c|}{$\begin{array}{l}\text { (A) Comparison of individual sequences to nucleic acid (GenBank release } 81.0 \text { for muscle library, and release } \\
84.0 \text { for brain library) and protein (SWISS-PROT) release 28) data bases allowed to classify each gene transcript } \\
\text { as Identical, Homolog, Related or Unknown. Further comparison with the partial CDNA sequence data base } \\
\text { subsection allowed detection of entries overlapping with any sequence of a registered gene transcript. Each } \\
\text { family having at least one entry overlapping one of its constitutive sequences was considered as Registered, } \\
\text { or New if not. } \\
\text { (B) Each gene transcript having one eSTS derived from one of its partial sequences was considered as Assigned, } \\
\text { or Known if identical to a human gene already mapped in GDB or GenBank. } \\
\text { (C) Some known genes (156) already mapped in GDB were also assigned in this study (GDB), and } 584 \\
\text { redundant eSTS allowing } 323 \text { pairwise comparisons (Multiple) were examined to assess the external and } \\
\text { internal accuracy of the method. The different eSTS markers were defined as Identical if they produced the } \\
\text { same result, Partial if they had one chromosome assignment in common, or Different. }\end{array}$} \\
\hline
\end{tabular}

fore, clone redundancy is no more a reflection of gene transcription. Another consequence of the normalization is that even though a large number of sequences have already been obtained from brain libraries, additional sequencing of this normalized library will continue to yield a large proportion of new gene transcripts (as shown in Table 1A; discussed in Berry et al. 1995).

\section{CHROMOSOMAL ASSIGNMENT}

Expressed sequence tagged site (eSTS) markers were derived from unique sequences, mainly those obtained from the $3^{\prime}$ end of the transcripts and assigned to specific chromosomes using panels of human-rodent somatic cell hybrids. Of the 2792 markers initially developed, most provided an unambiguous assignment, whereas 114 (3\%) detected several chromosomes (Auffray et al. 1995). To assess the coherence of the assignments, some eSTS markers were derived from known genes that had been localized previously, and in some cases, multiple eSTS markers were derived from different parts of the same transcript.

The sequence-clustering process described above allowed us to map at the chromosomal 


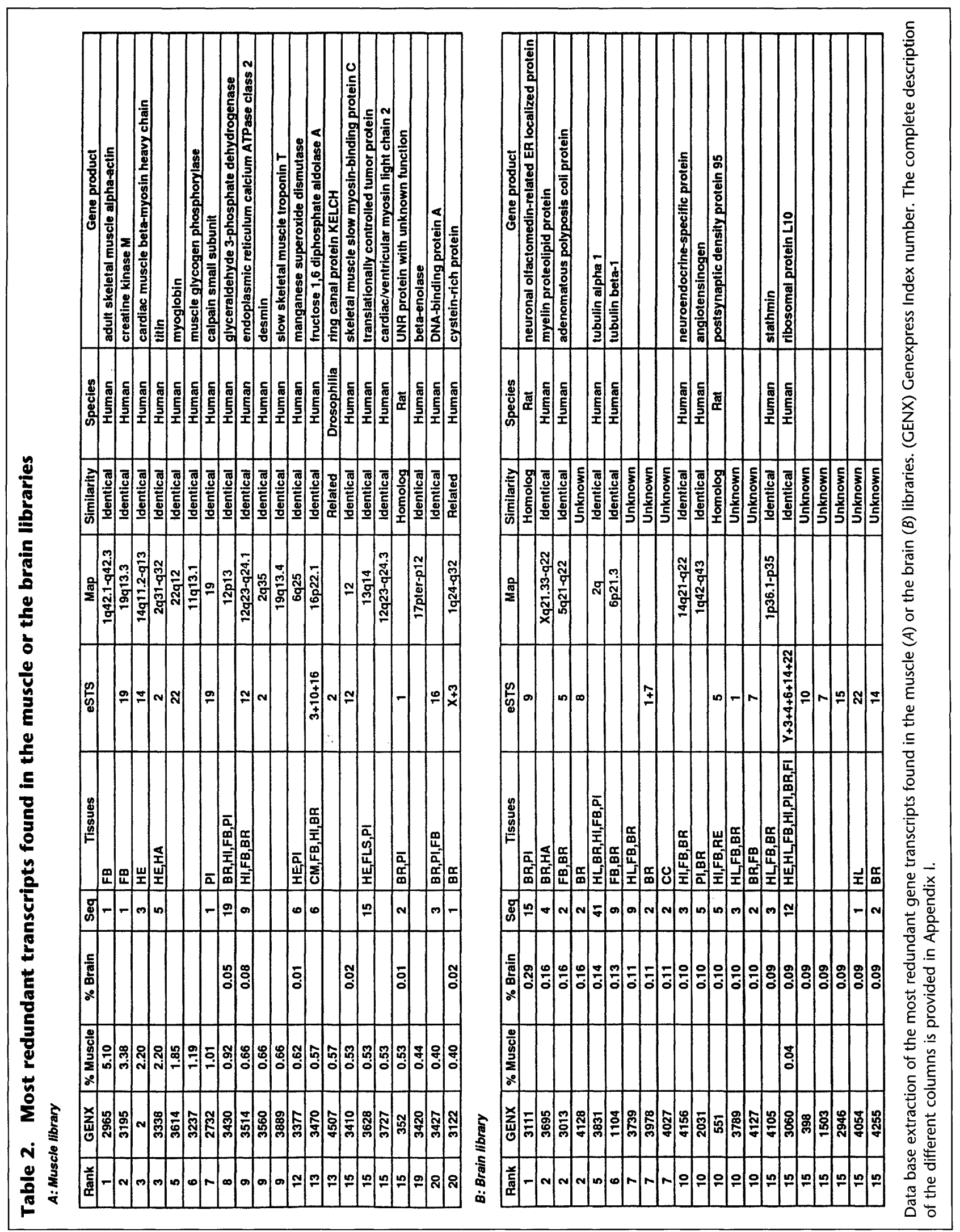


HOULGATTE ET AL.

\section{Table 3. Functional classification and global redundancy of all gene transcripts found in the muscle or brain libraries}

\begin{tabular}{|c|c|c|c|c|c|c|c|c|c|}
\hline \multicolumn{10}{|c|}{ A: Muscle Library } \\
\hline Clones & Cytoskeleton & $\begin{array}{c}\text { Nucleic-Acid } \\
\text { Managing }\end{array}$ & $\begin{array}{c}\text { Protein } \\
\text { Managing }\end{array}$ & Metabolism & $\begin{array}{c}\text { Recognition } / \\
\text { Adhesion }\end{array}$ & Signalling & $\begin{array}{c}\text { Transport / } \\
\text { Storage }\end{array}$ & Unclassified & Total \\
\hline Identical & 343 & 34 & 128 & 281 & 13 & 54 & 93 & 46 & 992 \\
\hline Homologous & 11 & 14 & 18 & 25 & 1 & 13 & 9 & 26 & 117 \\
\hline Related & 56 & 29 & 23 & 24 & 2 & 19 & 6 & 35 & 194 \\
\hline Unknown & & & & & & & & 978 & 978 \\
\hline Total & 410 & 77 & 169 & 330 & 16 & 86 & 108 & 1085 & 2281 \\
\hline Transcripts & Cytoskeleton & $\begin{array}{c}\text { Nucleic-Acid } \\
\text { Managing }\end{array}$ & $\begin{array}{c}\text { Protein } \\
\text { Managing }\end{array}$ & Metabolism & $\begin{array}{c}\text { Recognition / } \\
\text { Adhesion }\end{array}$ & Signalling & $\begin{array}{c}\text { Transport/ } \\
\text { Storage }\end{array}$ & Unclassified & Total \\
\hline Identical & 33 & 22 & 60 & 60 & 11 & 35 & 20 & 25 & 266 \\
\hline Homologous & 5 & 8 & 13 & 21 & 1 & 9 & 5 & 12 & 74 \\
\hline Related & 27 & 19 & 21 & 16 & 2 & 13 & 6 & 19 & 123 \\
\hline Unknown & & & & & & & & 828 & 828 \\
\hline Total & 65 & 49 & 94 & 97 & 14 & 57 & 31 & 884 & 1291 \\
\hline Redundancy & 6.31 & 1.77 & 1.80 & 3. 40 & 1.2 & 1.51 & 3.48 & 12,3 & 1.77 \\
\hline
\end{tabular}

B: Brain Library

\begin{tabular}{|c|c|c|c|c|c|c|c|c|c|}
\hline Clones & Cytoskeleton & $\begin{array}{l}\text { Nucleic-Acid } \\
\text { Managing }\end{array}$ & $\begin{array}{c}\text { Protein } \\
\text { Managing }\end{array}$ & Metabolism & $\begin{array}{c}\text { Recognition / } \\
\text { Adhesion }\end{array}$ & Signalling & $\begin{array}{c}\text { Transport / } \\
\text { Storage }\end{array}$ & Unclassified & Total \\
\hline Identical & 100 & 153 & 166 & 180 & 112 & 289 & 86 & 237 & 1323 \\
\hline Homologous & 17 & 22 & 35 & 33 & 6 & 76 & 38 & 99 & 326 \\
\hline Related & 36 & 112 & 82 & 69 & 32 & 108 & 30 & 161 & 630 \\
\hline Unknown & & & & & & & & 6419 & 6419 \\
\hline Total & 153 & 287 & 283 & 282 & 150 & 473 & 154 & 6916 & 8698 \\
\hline
\end{tabular}

\begin{tabular}{|c|c|c|c|c|c|c|c|c|c|}
\hline Transcripts & Cytoskeleton & $\begin{array}{l}\text { Nucleic-Acid } \\
\text { Managing }\end{array}$ & $\begin{array}{c}\text { Protein } \\
\text { Managing }\end{array}$ & Metabolism & $\begin{array}{c}\text { Recognition/ } \\
\text { Adhesion }\end{array}$ & Signalling & $\begin{array}{c}\text { Transport } / \\
\text { Storage }\end{array}$ & Unclassified & Total \\
\hline Identical & 41 & 100 & 81 & 96 & 50 & 150 & 41 & 133 & 692 \\
\hline Homologous & 8 & 16 & 16 & 22 & 4 & 36 & 23 & 38 & 163 \\
\hline Related & 21 & 74 & 53 & 45 & 22 & 72 & 17 & 101 & 405 \\
\hline Unknown & & & & & & & & 4384 & 4384 \\
\hline Total & 70 & 190 & 150 & 163 & 76 & 258 & 81 & 4656 & 5644 \\
\hline Redundancy & 2.19 & 1.57 & 1.39 & 1.7 & 197 & 1.83] & I90] & 1.9 & 1.54 \\
\hline
\end{tabular}

Each individual gene transcript found in this study was classified using an arborescent functional classification based on the information of their best matches extracted from data bases. Main functional classes presented here are Cytoskeleton, Nucleic-Acid Managing (proteins involved in structure, repairing, replication or transcription of nucleic acids), Protein Managing (proteins involved in translation, maturation, targeting or degradation of proteins), Metabolism, Recognition and Adhesion (protein involved in cell or tissue adhesion, or recognition such as MHC), Signaling (proteins involved in intra- or extracellular signaling such as hormones or growth factors and their receptors, or proteins involved in second messenger pathways), Transport and Storage (proteins involved in chelation of inorganic compounds, transport across cell membranes, or polypeptide binding proteins), or Unclassified (protein with no known function, or new gene transcripts with no significant similarity). Functional classes are presented in terms of number of clones (Clones) or gene transcripts (Transcripts), and global functional redundancy (Redundancy) is defined as the number of clones divided by the number of gene transcripts for each functional class. Note that the sum of the gene transcripts in the two libraries is not equal to the total number of gene transcripts presented in this study, as some of them are found in both libraries.

level at least 2272 new genes using 2733 eSTS markers (Table 1B). In most of the cases (86\%) when the corresponding gene had already been mapped, these eSTS markers provided a localization identical to that registered in GenBank or GDB (Table 1C). A better correlation (91\%) is ob- served for multiple assigments of the same transcript. The major causes of discrepancy appeared to be the presence of an intron in the amplified sequences leading to the mapping of a related gene or pseudogene. This is clearly the case for the human fructose biphosphate aldolase A gene 


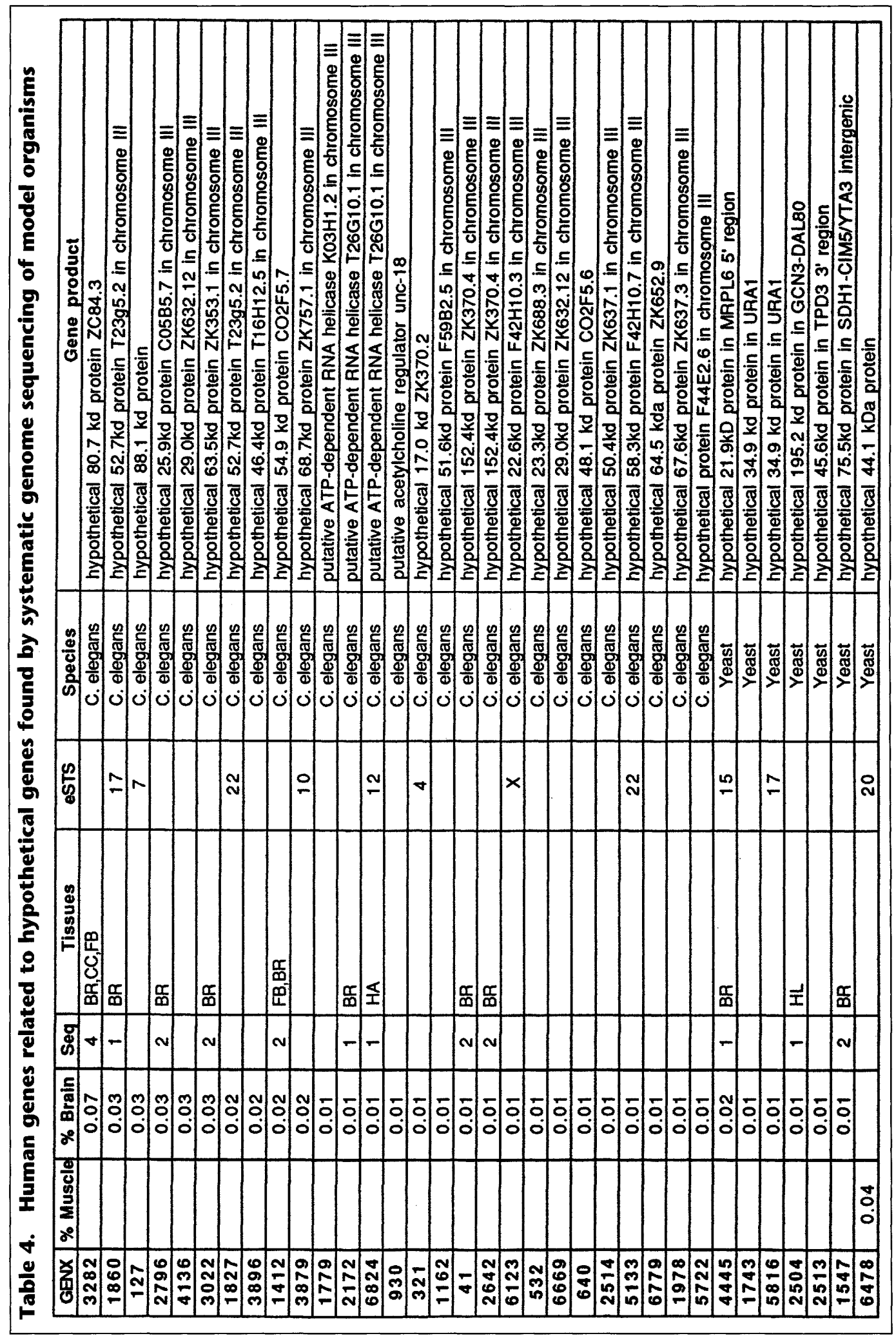


(ALDOA; GENX-3470), for which one eSTS marker out of four correctly localized this gene on chromosome 16, whereas one mapped to chromosome 10, and the remaining two to chromosome 3 and 10 , where the two aldolase A pseudogenes (ALDOAP1, ALDOAP2) are localized. Conversely, the four eSTS markers derived from the slow myosin binding protein $\mathrm{C}$ transcript (GENX-3410) and the six derived from the titin transcript (GENX-3338) always provided the same correct result (chromosome 12 and chromosome 2 , respectively).

\section{GENE TRANSCRIPT OVERVIEW}

An overview of the characteristics of the 6676 gene transcripts described in this study is provided in Appendix 1 (functional similarities) and Appendix 2 (accession numbers and eSTS markers). It should be clearly pointed out that positional or functional informations have been obtained in many instances from the analysis of different sequences derived from the same gene transcript. As this set of sequences do not form in most cases a single contig from which a consensus can be derived, all information is gathered through links at this stage.

Some of the gene transcripts display significant functional similarity with new putative genes characterized by the systematic sequencing of different genomes (Table 4). This provides independent evidence that they are transcribed, at least in man, and underlines the complementarity between genomic and partial cDNA sequencing approaches. This also indicates the importance of the integration of data from different organisms, as many functional features can be derived from the complete sequence of a gene in another species.

Another 27 gene transcripts are of particular interest because they appear to be derived from overlapping complementary strands of common segments of the genome. Figure 2 shows the sequence alignment of a gene transcript (GENX5024 ) overlapping with the human $\beta$-hexosaminidase gene in their $3^{\prime}$ regions. This gene transcript exhibits significant similarity with elongation factor $\mathrm{G}$ from Thermus aquaticus (Fig. 2B) as well as with that of yeast mitochondrial elongation factor $\mathrm{G}$ (not available in data bases at the time of the initial search). The better similarity with this last sequence suggests that the GENX-5024 transcript may encode the human mitochondrial form of this factor. The other putative overlapping genes are listed in Appendix $1 \mathrm{~F}$, including two of them that had already been described (Ashworth 1993; Tsai et al. 1994). Some show a complex overlap and must be confirmed by direct genome sequencing and further detailed transcript analyses.

The relatively important percentage $(0.4 \%)$ of putative overlapping gene transcripts found in this study suggests that the interaction between genes using common sequences for transcription or between mRNAs having complementary sequences is an important mechanism for the regulation of gene transcription. This may explain the conservation of some 3 '-end untranslated regions during evolution. This also suggests that a higher percentage of genes may share a common overlapping segment with another gene and that the percentage observed here by partial sequencing could have been underestimated.

The main utility of the Genexpress Index is to provide new candidates for genes involved in human pathology with special reference to neuromuscular pathologies. Table $5 \mathrm{~A}$ summarizes a set of 56 genes $(-6.5 \%$ of the known genes) that have been characterized in this study and that were already known to be defective in relation with human pathologies. In addition, 17 other transcripts display similarities with known defective genes (Table 5B) and could therefore represent candidates for orphan pathologies. If a percentage of $6.5 \%$ of defective genes is applied to the whole set of genes described in this study, we probably characterized more than 400 genes involved in human pathology. The utility of partial cDNA sequencing for the identification of genes involved in neuromuscular diseases is underlined by the fact that the recently cloned Survival Motor Neuron gene (Lefebvre et al. 1995) involved in spinal atrophy was registered early in this study (GENX-4903).

\section{CONCLUSIONS AND PERSPECTIVES}

Partial sequencing of cDNA clones and chromosomal assignment of the corresponding genes are the preliminary steps in the identification of disease genes and need to be integrated in a more general way, including complete sequencing, precise mapping, and detailed expression, and functional studies. This is the purpose of the IMAGE consortium in which laboratories of various size and expertise collaborate worldwide to char- 
A)

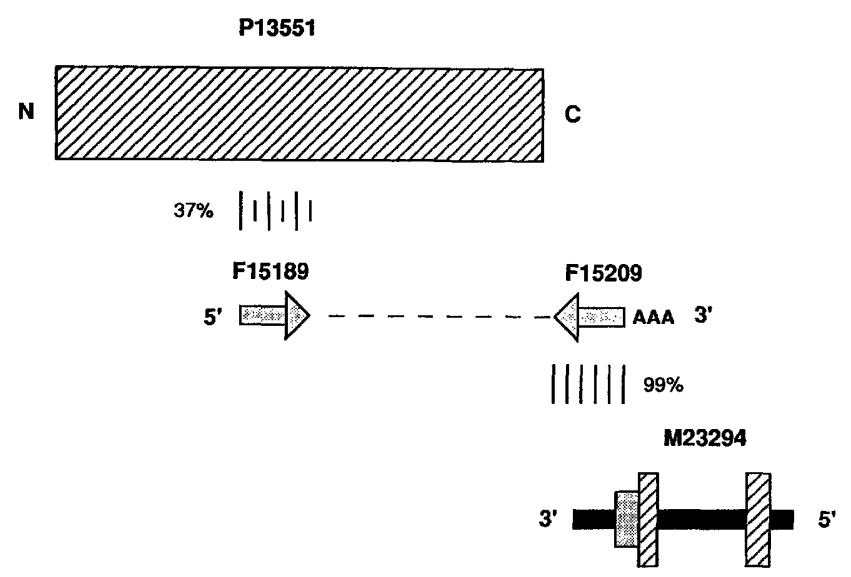

B)

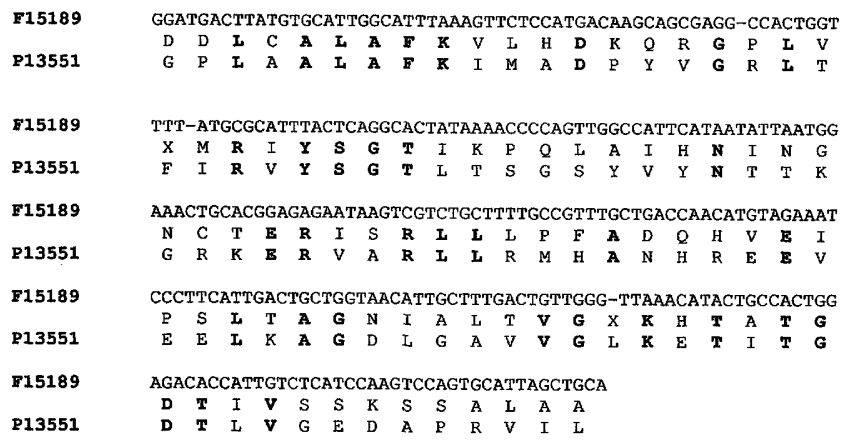

C)

\begin{tabular}{|c|c|}
\hline F'15209 & TAAAATATTTTTATTGATTG \\
\hline 423294 & ATAAAATATTTTTATTGATTGAACCTTTGACCCTCTATCTTATTACAT \\
\hline M13519 & МATAAAATATTTTTATTGATTGAA \\
\hline F15209 & AGAGGCCTGGCATCTTTCTTGTGAGACAAGCTTAAGGACACAAA \\
\hline M23294 & AGAGGCCTGGCATCTTTCTTGTGAGACAAGCTTAAGGACACAAAAGAA \\
\hline F15209 & AACTTTGTGATACCACTCT-CTGAAGGCTACTTATAGTAATAA \\
\hline M23294 & AACTTTGTGATACCACTCTTCTGAAGGCTACTTATAGTAATAACTTCA \\
\hline F15209 & GA-CAGCATGATTCAGGTACAGTGGCTTTAAACATCAAAGCACA \\
\hline M23294 & TGAACAGCATGATTCAGGTACAGTGGCTTTAAACATCAAAGCACATTT \\
\hline F15209 & TATAAATTAAAACGGGTGGCTCCAGTGCCACTATCAAAGCTTA \\
\hline
\end{tabular}

acterize common ordered collections of cDNA clones by a variety of complementary approaches. This includes positioning of all the genes characterized in this study in the integrated genetic, cytogenetic, and physical maps of the human genome using DNA fragments cloned in yeast artificial chromosomes (YACs) and other vectors and rearrangement, breakpoint, and radiation reduced somatic cell hybrids (Cox et al. 1990; Weissenbach et al. 1992; Cohen et al. 1993; Gyapay et al. 1994; Walter et al. 1994; Chumakov
Figure 2 Overlapping genes. (A) Schematic representation of a gene transcript (GENX-5024) related to $T$. aquaticus elongation factor $G$ (P13551) and overlapping the human gene encoding $\beta$-hexosaminidase (M23294). Partial CDNA sequences are shown as arrows, coding regions, or proteins as hatched boxes, 3'-untranslated regions as dotted boxes, and introns or genomic DNA as solid boxes. Broken lines indicate unsequenced parts of the cDNA clones. Accession numbers are above their representation. Note that this transcript overlaps by 25 bp with the $\beta$-hexosaminidase transcript (GenBank M13519, not shown) and is identical to the untranscribed genomic DNA downstream of this gene. (B) Sequence alignments of the $5^{\prime}$ end sequence of GENX-5024 (lane 1) and its putative translation (lane 2) with $T$. aquaticus elongation factor $G$. ( $C$ ) Sequence alignments of the $3^{\prime}$ end sequence of GENX-5024 (F15209) with the genomic (M23294) and the mRNA (M13519) sequences of the human $\beta$-hexosaminidase gene. Poly(A) signals are shown in boldface.

et al. 1995). The availability of the 2792 eSTS markers that we have developed (Auffray et al. 1995), together with $>1200$ others developed by Dr. Polymeropoulos (Polymeropoulos et al. 1992, 1993; M. Polymeropoulos, pers. comm.), provide the opportunity to double the number of mapped genes and therefore enhance the probability of identifying those involved in human pathologies.

The value of this resource to complement the positional paradigm (Collins 1995) is exemplified by the process that led to the identification of the gene responsible for the recessive form of limbgirdle muscular dystrophy (Richard et al. 1994, 1995; Chiannikulchai et al. 1995). In monitoring the progress of the genic map, toward the goal of 100-kb resolution (Cox et al. 1994), intervals of 50-250 Mb (chromosome), 10-50 Mb (cytogenetic interval), $1-10 \mathrm{Mb}$ (integrated genetic map), and $<1 \mathrm{Mb}$ (cloned and mapped DNA fragment) are important milestones. As it is estimated that the human genome contains some 60,000 to 80,000 genes (Antequera and Bird 1993, 1994; Fields et al. 1994), the current genic map is only $-10 \%$ complete at the first level of chromosomal resolution. To contribute to the progress toward a dense and comprehensive genic map, we are currently extending the set of eSTS markers to the remaining indexed genes in collaboration with IMAGE consortium collaborators. This has already allowed regional localiza- 
HOULGATTE ET AL.

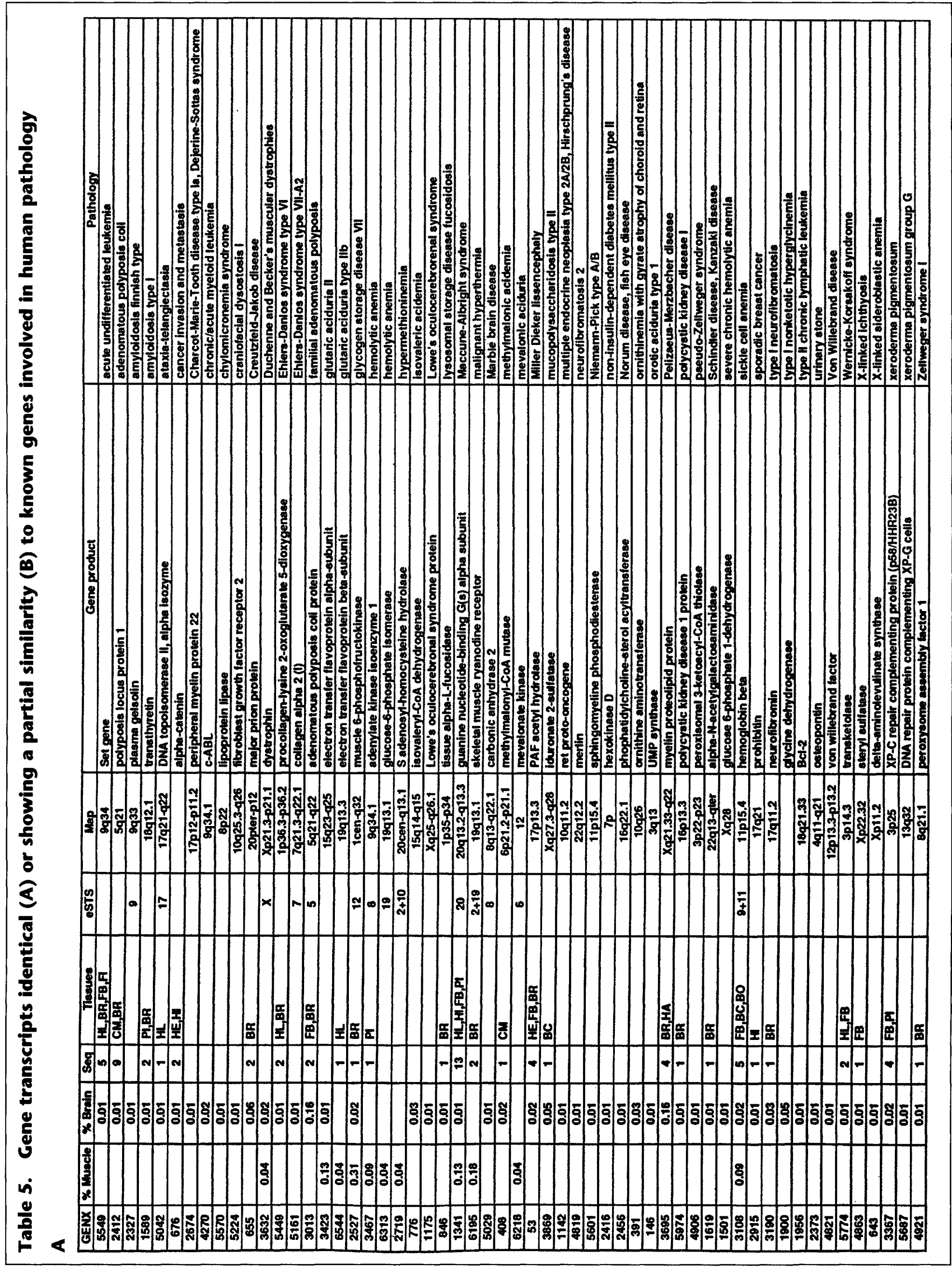




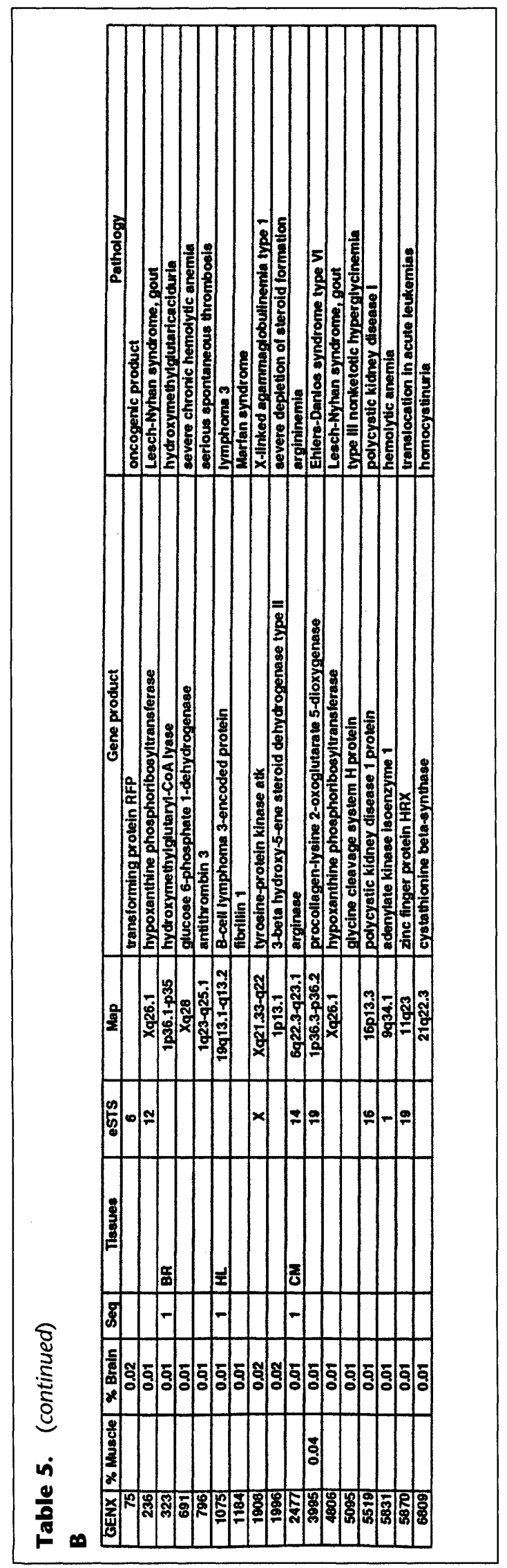




\section{HOULGATTE ET AL.}

tion of eSTS markers assigned to several chromosomes at one to a few megabase resolution (Callen et al. 1995; Rosier et al. 1995; C. Auffray et al., unpubl.).

As a fraction of $\sim 15 \%$ of the eSTS markers also amplify the corresponding genes in the mouse, it will be possible to use them directly to integrate the human and mouse maps. These markers are also versatile tools that can be used in RT-PCR experiments to monitor the expression profiles of the transcripts in a large number of tissues, cell lines, and species in various physiological and pathological situations. Cross-referencing with the results collected in the study of the genomes of other model organisms will be instrumental in deciphering the functions of the large number of new genes indexed in this study and other similar programs.

\section{MATERIAL AND DATA AVAILABILITY}

The cDNA sequences have been registered to the EMBL Data Library, and the eSTS markers in GDB. The Genexpress index is available on the Internet by anonymous FTP at the address ftp.infobiogen.fr in the /pub/db/Genexpress directory with the associated help file READ_ME. In addition, they can be downloaded or consulted on the Genome Research World Wide Web server at address http://www.cshl.org. Information on the IMAGE Consortium is available from Dr. Greg Lennon, Department of Energy Genome Center, Lawrence Livermore: http://www.bio.llnl.gov/ bbrp/genome/genome.htlm; cDNA clones can be obtained from Dr. Hans Lerach, Reference Library Data Base, Max Planck Institute für Molekulare Genetik, Berlin, Germany: http://gea.lif.icnet.uk/ and from Dr. Keith Gibson, Human Genome Program Resource Center, Hinxton, UK: http:// www.hgmp.mrc.uk/. Primer pairs will be available from Research Genetics. Other requests concerning additional information and reagents should be directed to the Email address: Remi@pauline.vjf.inserm.fr.

\section{NOTE ADDED IN PROOF}

Adams et al. (1995. Nature 377: S3-S174) have described an "Initial assessment of human gene diversity and expression patterns based on 83 million nucleotides of cDNA sequence" at the time this paper was accepted for publication.

\section{ACKNOWLEDGMENTS}

We thank all members of the Genexpress Pro- gram team and the staff at Généthon and CNRS for their dedication and support. The IMAGE consortium is coordinated by C.A. in collaboration with Dr. Greg Lennon at the Department of Energy Genome Center in Livermore, Dr. Mihaelis Polymeropoulos at the National Center for Human Genome Research, National Institutes of Health, Bethesda, and Dr. Bento Soares at Columbia University, New York. The Genexpress Program is supported by Association Française contre les Myopathies (AFM), CNRS, and grants from the Ministère de la Recherche et de l'Espace (MRE), Groupement de Recherches et d'Etudes de Génomes (GREG), and the European Union Biomed 1 Program to C.A.

The publication costs of this article were defrayed in part by payment of page charges. This article must therefore be hereby marked "advertisement" in accordance with 18 USC section 1734 solely to indicate this fact.

\section{REFERENCES}

Adams, M.D., J.M. Kelley, J.D. Gocayne, M. Dubnick, M.H. Polymeropoulos, H. Xiao, C.R. Merril, A. Wu, B. Olde, R.F. Moreno, A.R. Kerlavage, W.R. McCombie, and J.C. Venter. 1991. Complementary DNA sequencing: Expressed sequence tags and Human Genome project. Science 252: 1651-1656.

Adams, M.D., M. Dubnick, A.R. Kerlavage, R. Moreno, J.M. Kelley, T.R. Utterback, J.W. Nagle, C. Fields, and J.C. Venter. 1992. Sequence identification of 2,375 human brain genes. Nature 355: 632-635.

Adams, M.D., A.R. Kerlavage, C. Fields, and J.C. Venter. 1993a. 3,400 new expressed sequence tags identify diversity of transcripts in human brain. Nature Genet. 4: $256-267$.

Adams, M.D., M.B. Soares, A.R. Kerlavage, C. Fields, and J.C. Venter. 1993b. Rapid cDNA sequencing (expressed sequence tags) from a directionally cloned human infant brain cDNA library. Nature Genet. 4: 373-380.

Affara, N.A., E. Bentley, P. Davey, A. Pelmear, and M.H. Jones. 1994. The identification of novel gene sequences of the human adult testis. Genomics 22: 205-210.

Altschul, S.F., W. Gish, W. Miller, E.W. Myers, and D.J. Lipman. 1990. Basic local alignment search tool. J. Mol. Biol. 215: $403-410$.

Altschul, S.F., M.S. Boguski, W. Gish, and J.C. Wooton. 1994. Issues in searching molecular sequence databases. Nature Genet. 6: 119-129.

Antequera, F. and A. Bird. 1993. Number of CpG islands 


\section{GENEXPRESS INDEX}

and genes in human and mouse. Proc. Natl. Acad. Sci. 90: 11995-11999.

1994. Predicting the total number of human genes. Nature Genet. 8: 114.

Ashworth, A. 1993. Two acetyl-CoA acetyltransferase genes located in the $t$-complex region of the mouse chromosome 17 partially overlap the Tcp-1 and Tcp-1x genes. Genomics 18: 195-198.

Auffray, C., B. Béhar, F. Bois, C. Bouchier, C. Da Silva, M.-D. Devignes, S. Duprat, R. Houlgatte, M.-N. Jumeau, B. Lamy, F. Lorenzo, H. Mitchell, R. Mariage-Samson, G. Piétu, Y. Pouliot, C. Sébastiani-Kabaktchis, and A. Tessier. 1995. IMAGE : Integrated Molecular Analysis of the human Genome and its Expression. C.R. Acad. Sci. Paris (Life sciences) 318: 263-272.

Bairoch, A. and B. Boeckmann. 1994. The Swiss-Prot protein sequence data bank: Current status. Nucleic Acids Res. 22: $3578-3580$.

Benson, D.A., M. Boguski, D.J. Lipman, and J. Ostell. 1994. GenBank. Nucleic Acids Res. 22: 3441-3444.

Berry, R., T.J. Stevens, N.A.R. Walter, A.S. Wilcox, T. Rubano, J.A. Hopkins, J. Weber, R. Goold, M.B. Soares, and J.M. Sikela. 1995. Gene-based sequence-tagged-sites (STSs) as the basis for a human gene map. Nature Genet. 10: $415-423$.

Brenner, S. 1990. The human genome: The nature of the enterprise. CIBA Found. Symp. 149: 6-17.

Callen, D., S.A. Lane, H. Kozman, G. Kremmidiotis, S.A. Whitmore, M. Lowenstein, N.A. Doggett, N. Kenmochi, D.C. Page, D.R. Maglott, W.C. Nierman, K. Murakawa, R. Berry, J.M. Sikela, R. Houlgatte, C. Auffray, and G.R. Sutherland. 1995. Integration of transcript and genetic maps of chromosome 16 at near $1 \mathrm{Mb}$ resolution: Demonstration of a hot spot for recombination at 16p12. Genomics 29: 503-511.

Chen, E., M. d'Urso, and D. Schlessinger. 1994. Functional mapping of the human genome by cDNA localization versus sequencing. BioEssays 16: 693-698.

Chiannikulchai, N., P. Pasturaud, I. Richard, C. Auffray, and J. Beckmann. 1995. An expression map of the chromosome $15 q 15$ region, containing a gene for the recessive form of limb-girdle muscular dystrophy, LGMD2A. Hum. Mol. Genet. 4: 717-725.

Chumakov, I.M., P. Rigault, I. LeGall, C. Bellané-Chantelot, A. Billault, S. Guillou, P. Soularue, G. Guasconi, E. Poullier, I. Gross, et al. 1995. A YAC contig map of the human genome. Nature 377: S175-S297.

Claverie, J.-M. and D. States. 1993. Information enhancement methods for large scale sequence analysis. Comput. Chem. 17: 191-201.

Cohen, D., I. Chumakov, and J. Weissenbach. 1993.
Première génération de la carte physique du génome humain. C.R. Acad. Sci. Paris (Life Sciences)

316: 1484-1488.

Collins, F.S. 1995. Positional cloning moves from perditional to traditional. Nature Genet. 9: 347-350.

Collins, F. and D. Galas. 1993. A new five-year plan for the US human genome project. Science 262: 43-46.

Cox, D.R., M. Burmeister, E.R. Price, S. Kim, and R.M. Myers. 1990. Radiation hybrid mapping: A somatic cell genetic method for constructing high resolution maps of mammalian chromosomes. Science 250: 245-250.

Cox, D.R., E.D. Green, E.S. Lander, D. Cohen, and R.M. Myers. 1994. Assessing mapping progress in the human genome project. Science 265: 2031-2032.

Davies, R.W., A.B. Roberts, A.J. Morris, G.W. Griffith, J. Jerecic, S. Ghandi, K. Kaiser, and A. Savioz. 1994. Enhanced access to rare brain cDNAs by prescreening libraries: 207 new mouse brain ESTs. Genomics 24: $456-463$.

Durkin, A.S., D.R. Maglott, and W.C. Nierman. 1992. Chromosomal assignment of 38 human brain expressed sequence tags (ESTs) by analyzing fluorescently labeled PCR products from hybrid cell panels. Genomics 14: $808-810$.

Efstratiadis, A., F.C. Kafatos, A.M. Maxam, and T. Maniatis. 1976. Enzymatic in vitro synthesis of globin genes. Cell 7: 279-288.

Fasman, K.H., A.J. Cuticchia, and D.T. Kingsbury. 1994. The GDB human genome database anno 1994. Nucleic Acids Res. 22: 3462-3469.

Fields, C., M.D. Adams, O. White, and J.C. Venter. 1994. How many genes in the human genome? Nature Genet. 7: 345-346.

Franco, G.R., M.D. Adams, M.B. Soares, A.J. Simpson, J.C. Venter, and S.D. Pena. 1995. Identification of new Schistosoma mansoni genes by the EST strategy using a directional cDNA library. Gene 152: 141-147.

Frigerio, J.M., P. Berthezene, P. Garrido, E. Ortiz, S. Barthellemy, S. Vasseur, B. Sastre, I. Seleznieff, J.C. Dagorn, and J.L. Iovanna. 1995. Analysis of 2166 clones from a human colorectal cancer cDNA library by partial sequencing. Hum. Mol. Genet. 4: 37-43.

Fukushima, A., K. Okubo, H. Sugino, N. Hori, R. Matoba, T. Niiyama, K. Murakawa, J. Yoshii, M. Yokoyama, and K. Matsubara. 1994. Chromosomal assignment of HepG2 3 '-directed partial cDNA sequences by Southern blot hybridization using monochromosomal hybrid cell panels. Genomics 22: 127-136.

Gieser, L. and A. Swaroop. 1992. Expressed sequence tags and chromosomal localization of cDNA clones from a 


\section{HOULGATTE ET AL.}

subtracted retinal pigment epithelium library. Genomics 13: $873-876$.

Gish, W. and D.J. States. 1993. Identification of protein coding regions by database similarity search. Nature Genet. 3: 266-272.

Grausz, D. and C. Auffray. 1993. Strategies in cDNA programs. Genomics 17: 530-532.

Gyapay, G., J. Morissette, A. Vignal, C. Dib, C. Fizames, P. Millasseau, S. Marc, G. Bernardi, M. Lathrop, and J. Weissenbach. 1994. The 1993-94 Généthon human genetic linkage map. Nature Genet. 7: 246-339.

Hochgeschwender, V. 1992. Toward a transcriptional map of the human genome. Trends Genet. 8: 41-44.

Höfte, H., T. Desprez, J. Amselem, H. Chiapello, M. Caboche, A. Moisan, M.F. Jourjon, J.L. Charpenteau, P. Berthomieu, D. Guerrier, J. Giraudat, F. Quigley, F. Thomas, D.Y. Yu, R. Mache, M. Raynal, R. Cooke, F. Grellet, M. Delseny, Y. Parmentier, G. Marcillac, C. Gigot, J. Fleck, G. Philipps, M. Axelos, C. Bardet, D. Tremousaygue, and B. Lescure. 1993. An inventory of 1152 expressed sequence tags obtained by partial sequencing of cDNAs from Arabidopsis thaliana. Plant $J$. 4: $1051-1061$.

Höög, C. 1991. Isolation of a large number of novel mammalian genes by a differential cDNA library searching strategy. Nucleic Acids Res. 19: 6123-6127.

Hyde, D.R., K.L. Mecklenburg, J.A. Pollock, T.S. Vihtelic, and S. Benzer. 1991. Twenty Drosophila visual system cDNA clones: One is homolog of human arrestin. Proc. Natl. Acad. Sci. 87: 1008-1012.

Kato, K. 1990. A collection of cDNA clones with specific expression patterns in mouse brain. Eur. J. Neurosci. 2: 704-711.

1992. Finding new genes in the nervous system by cDNA analysis. Trends Neurosci. 15: 319-323.

Kerr, S.M., S. Vambrie, S.J. McKay, and H.J. Cooke. 1994. Analysis of cDNA sequences from mouse testis. Mammalian Genome 5: 557-565.

Khan, A.S., A.S. Wilcox, M.H. Polymeropoulos, J.A. Hopkins, T.J. Stevens, M. Robinson, A.K. Orpana, and J.M. Sikela. 1992. Single pass sequencing and physical and genetic mapping of human brain cDNAs. Nature Genet. 2: 180-185.

Konishi, K., Y. Morishima, E. Ueda, Y. Kibe, K. Nonomura, K. Yamanishi, and H. Yasuno. 1994. Cataloguing of genes expressed in human keratinocytes: Analysis of 607 randomly isolated cDNA sequences. Biochem. Biophys. Res. Commun. 202: 976-983.

Kurata, N., Y. Nagamura, K. Yamamoto, Y. Harushima, N. Sue, J. Wu, B.A. Antonio, A. Shomura, T. Shimizu, S.Y. Lin, T. Inoue, A. Fukuda, T. Shimano, Y. Kuboki, T.
Toyama, Y. Miyamato, T. Kirihara, K. Hayasaka, A. Miyao, L. Monna, H.S. Zhong, Y. Tamura, Z.X. Wang, T. Momma, Y. Umehara, M. Yano, T. Sasaki, and Y. Minobe. 1994. A 300 kilobase interval genetic map of rice including 883 expressed sequences. Nature Genet. 8: $365-372$.

Lefebvre, S., L. Bürglen, S. Reboullet, O. Clermont, P. Burlet, P. Viollet, B. Bénichou, C. Cruaud, P. Millasseau, M. Zeviani, D. Le Paslier, J. Frézal, D. Cohen, J. Weissenbach, A. Munnich, and J. Melki. 1995. Identification and characterization of a spinal muscular atrophy-determining gene. Cell 80: 155-165.

Liew, C.C., D.M. Hwang, Y.W. Fung, C. Laurenssens, E. Cukerman, S. Tsui, and C.Y. Lee. 1994. A catalogue of genes in the cardiovascular system as identified by expressed sequence tags. Proc. Natl. Acad. Sci. 91: 10645-10649.

Matsubara, K. and K. Okubo. 1993. Identification of new genes by systematic analysis of cDNAs and database construction. Curr. Opin. Biotech. 4: 672-677.

McCombie, W.R., M.D. Adams, J.M. Kelley, M.G. FitzGerarld, T.R. Utterback, M. Khan, M. Dubnick, A.R. Kerlavage, J.C. Venter, and C. Fields. 1992. Caenorhabditis elegans expressed sequence tags identify gene families and potential disease gene homologues. Nature Genet. 1: 124-131.

Milner, R.J. and J.G. Sutcliffe. 1983. Gene expression in rat brain. Nucleic Acids Res. 11: 5497-5517.

Murakawa, K., K. Matsubara, A. Fukushima, J. Yoshii, and K. Okubo. 1994. Chromosomal assignments of 3'-directed partial cDNA sequences representing novel genes expressed in granulocytoid cells. Genomics 23: 379-389.

Newman, T., F.J. de Bruijn, P. Green, K. Keegstra, H. Kende, L. McIntosh, J. Ohlrogge, N. Raikhel, S. Somerville, M. Thomashow, E. Retzel, and C. Somerville. 1994. Genes galore: A summary of methods for accessing results from the large-scale partial sequencing of anonymous Arabidopsis cDNA clones. Plant Physiol. 106: $1241-1255$.

Nishiguchi, S., T. Joh, K. Horie, Z. Zou, T. Yasunaga, and K. Shimada. 1994. A survey of genes expressed in undifferentiated mouse embryonal carcinoma F9 cells: Characterization of low-abundance mRNAs. J. Biochem. 116: 128-139.

Nomura, N., N. Miyajima, T. Sazuka, A. Tanaka, Y. Kawarahayasi, S. Sato, T. Nagase, N. Seki, K. Ishikawa, and S. Tabata. 1994. Prediction of the coding sequences of unidentified human genes. 1 . The coding sequences of 40 new genes (KIAA0001-KIAA0040) deduced by analysis of randomly sampled cDNA clones from human immature myeloid cell line KG-1. DNA Res. 1: 27-35.

Okubo, K., H. Hori, R. Matuba, T. Niiyama, and K. Matsubara. 1991. A novel system for large-scale 


\section{GENEXPRESS INDEX}

sequencing of cDNA by PCR amplification. DNA Sequence 2: 137-144.

Okubo, K., H. Hori, R. Matuba, T. Niiyama, A. Fukushima, Y. Kojima, and K. Matsubara. 1992. Large scale cDNA sequencing analysis of quantitative and qualitative aspects of gene expression. Nature Genet. 2: $173-179$.

Okubo, K., J. Yoshii, H. Yokouchi, M. Kameyama, and K. Matsubara. 1994. An expression profile of active genes in human colonic mucosa. DNA Res. 1: 37-45.

Palazzolo, M.J., D.R. Hyde, K. VijayRaghavan, K. Mecklenburg, S. Benzer, and E. Meyerowitz. 1987. Use of a new strategy to isolate and characterize 436 drosophila cDNA clones corresponding to RNAs detected in adult heads but not in early embryos. Neuron 3: 527-539.

Park, Y.S., J.M. Kwak, O. Kwon, Y.S. Kim, D.S. Lee, M.J. Cho, H.H. Lee, and H.G. Nam. 1993. Generation of expressed sequence tags of random root cDNA clones of Brassica napus by single-run partial sequencing. Plant Physiol. 103: 359-370.

Parrish, J.E. and D.L. Nelson. 1993. Methods for finding genes a major rate-limiting step in positional cloning. Genet. Anal. Techniques Applic. 10: 29-41.

Pawlak, A., C. Toussaint, I. Lévy, F. Bulle, M. Poyard, R. Barouki, and G. Guellaën. 1995. Characterization of a large population of mRNAs from human testis. Genomics 26: $151-158$.

Pearson, W.R. 1990. Rapid and sensitive sequence comparison with FASTP and FASTA. Methods Enzymol. 183: 63-98.

Pearson, P., C. Francomano, P. Foster, C. Bocchini, P. Li, and V. McKusick. 1994. The status of On line Mendelian Inheritance in Man (OMIM) medio 1994. Nucleic Acids Res. 22: 3470-3473.

Polymeropoulos, M.H., H. Xiao, J.M. Sikela, M. Adams, J.C. Venter, and C.R. Merril. 1992. Chromosomal assignment of 46 brain cDNAs. Genomics 12: 492-496.

1993. Chromosomal distribution of 320 genes from a brain cDNA library. Nature Genet. 4: 381-386.

Putney, S.D., W.C. Herlihy, and P. Schimmel. 1983. A new troponin $\mathrm{T}$ and cDNA clones for 13 different muscle proteins, found by shotgun sequencing. Nature 302: 718-721.

Richard, I., O. Broux, N. Chiannilkulchai, F. Fougerousse, V. Allamand, N. Bourg, L. Brenguier, C. Devaud, P. Pasturaud, C. Roudaut, F. Lorenzo, C. Sébastiani-Kabaktchis, R.A. Schultz, M.H. Polymeropoulos, G. Gyapay, C. Auffray, and J.S. Beckmann. 1994. Regional localization of human chromosome 15 loci. Genomics 23: 1001-1009.

Richard, I., O. Broux, V. Allamand, F. Fougerousse, N.
Chiannilkulchai, N. Bourg, L. Brenguier, C. Devaud, P. Pasturaud, C. Roudaut et al. 1995. Mutations in the proteolytic enzyme calpain 3 cause limb-girdle muscular dystrophy type 2A. Cell 81: 27-40.

Rosier, M.-F., I. Reguigne-Arnould, P. Couillin, M.-D. Devignes, and C. Auffray. 1995. Regional assignment of 68 new human gene transcript on chromosome 11 . Genome Res. 5: 60-70.

Rougeon, F., P. Kourilsky, and B. Mach. 1975. Insertion of a rabbit $\beta$-globin gene sequence into an $E$. coli plasmid. Nucleic Acids Res. 2: 2365-2378.

Sasaki, T., J. Song, Y. Koga-Ban, E. Matsui, F. Fang, H. Higo, H. Nagasaki, M. Hori, M. Miya, E. Murayama-Kayano, T. Takiguchi, A. Takasuga, T. Niki, K. Ishimaru, H. Ikeda, Y. Yamamoto, Y. Mukai, I. Ohta, N. Miyadera, I. Havukkala, and Y. Minobe. 1994. Toward cataloguing all rice genes: Large-scale sequencing of randomly chosen rice cDNAs from a callus CDNA library. Plant J. 6: 615-624.

Sikela, J. and C. Auffray. 1993. Finding new genes faster than ever. Nature Genet. 3: 189-191.

Smith, L.M., W. Hunkapiller, T.J. Hunkapiller, and L.E. Hood. 1985. The synthesis of oligonucleotides containing an aliphatic amino group at the $5^{\prime}$ terminus: Synthesis of fluorescent DNA primers for use in DNA sequence analysis. Nucleic Acids Res. 13: 2399-2412.

Smith, L.M., J.Z. Sanders, R.J. Kaiser, P. Hughes, C. Dodd, C.R. Connell, C. Heiner, S.B.H. Kent, and L.E. Hood. 1986. Fluorescence detection in automated DNA sequence analysis. Nature 321: 674-679.

Soares, M.B., M.D.F. Bonaldo, P. Jelenc, L. Su, L. Lawton, and A. Efstratiadis. 1994. Construction and characterization of a normalized cDNA library. Proc. Natl. Acad. Sci. 91: 9228-9232.

Southern, E.M. 1992. Genome mapping: cDNA approaches. Curr. Opin. Genet. Dev. 2: 412-416.

Sudo, K., K. Chinen, and Y. Nakamura. 1994. 2058 expressed sequence tags (ESTs) from a human fetal lung cDNA library. Genomics 24: 276-279.

Sutcliffe, J.G. 1988. mRNA in the mammalian central nervous system. Annu. Rev. Neurosci. 11: 157-198.

Takeda, J., H. Yano, S. Eng, Y. Zeng, and G.I. Bell. 1993. A molecular inventory of human pancreatic islets: Sequence analysis of $1000 \mathrm{cDNA}$ clones. Hum. Mol. Genet. 2: 1793-1798.

Tsai, J.-Y., M.L. Namin-Gonzales, and L.M. Silver. 1994. False association of human ESTs. Nature Genet. 8: $321-322$.

Uchimiya, H., S. Kidou, T. Shimazaki, S. Takamatsu, H. Hashimoto, R. Nishi, S. Aotsuka, Y. Matsubayashi, N. Kidou, M. Umeda, and A. Kato. 1992. Random 


\section{HOULGATTE ET AL.}

sequencing of cDNA libraries reveals a variety of expressed genes in cultured cells of rice (Oryza sativa L.). Plant J. 2: 1005-1009.

Walter, M.A., D.J. Spillett, P. Thomas, J. Weissenbach, and P. Goodfellow. 1994. A method for constructing radiation hybrid maps of whole genomes. Nature Genet. 7: $22-28$.

Waterston, R., C. Martin, M. Craxton, C. Huynh, A. Coulson, L. Hillier, R. Durbin, P. Green, R. Shownkenne, N. Halloran, M. Metzstein, T. Hawkins, R. Wilson, M. Berks, Z. Du, K. Thomas, J. Thierry-Mieg, and J. Sulston. 1992. A survey of expressed genes in Caenorhabditis elegans. Nature Genet. 1: 114-123.

Weissenbach, J., G. Gyapay, C. Dib, A. Vignal, J. Morissette, P. Millasseau, G. Vaysseix, and M. Lathrop. 1992. A second-generation linkage map of the human genome. Nature 359: 794-801.

Wilcox, A.S., A.S. Khan, J.A. Hopkins, and J.M. Sikela. 1991. Use of 3' untranslated sequences of human cDNAs for rapid chromosome assignment and conversion to STSs: Implications for an expression map of the genome. Nucleic Acids Res. 19: 1837-1843.

Received July 13, 1995; accepted in revised form September 28, 1995.

\section{APPENDICES: THE GENEXPRESS INDEX}

Only a small fraction of Appendices 1D and 2A-B are shown in print as examples. The remaining parts are available as an electronic supplement together with the full text of the other appendices at http://www.cshl.org/ in the Genome Research section. Please follow the links from the home page.

\section{APPENDIX I: FUNCTIONAL SIMILARITIES}

Classification of each gene transcript has been designated as Known (A), Homolog (B), Related (C), or Unknown (D) on the basis of data base similarities. A special classification was necessary for Overlapping transcripts (E), or New transcripts in known (already sequenced) regions (F).

Information available in Appendix I are the Genexpress Index number (GENX), the clone frequency in muscle (\% muscle) or brain (\% brain) libraries, the number of partial cDNA sequences registered in public data bases linked to this gene transcript (Seq), the chromosomal localization obtained with Genexpress eSTS markers (eSTS), or already available in GDB or GenBank (Map), the species (Species), and gene product name
(Gene Product). In new (E) or overlapping (F) subsections, "DNA region" or "overlapped gene" refer to the gene product name having an identical or overlapping sequence, whereas "similarity" and "gene product" refer to the true functional similarity of the transcript.

"Tissues" indicates the origin of the cDNA partial sequences, abbreviated as follows: (AE) aortic endothelium; (BC) adult brain cortex; (BO) adult bone; (BR) brain; (BS) brain striatum; (CC) colorectal cancer; (CM) colon mucosa; (EK) epidermis keratinocyte; (FA) fetal adrenals; (FB) fetal brain; (FI) fibroblast; (FK) fetal kidney; (FLS) fetal liver and spleen; (HA) heart atrium; (HE) heart; (HG) HepG2 liver cell line; (HI) hippocampus; (HL) HL60 cell line; (LF) lung fibroblast; (LI) liver; (PI) pancreatic islets; (PL) placenta; (RE) retinal pigment epithelium; (RH) adult rhabdomyosarcoma cell line; (TC) temporal cortex; (TE) adult testis; (TH) THP-1 cell line; (UN) unclassified. A few gene transcripts were found identical to short genomic sequences such as STSs and were classified in the "known gene transcripts" subsection, to show their similarity, even though they should be considered as new gene transcripts.

\section{APPENDIX II: DATA BASE CROSS-INDEXES}

Indicated are accession numbers (A) or eSTS markers (B) linked to the different gene transcripts. The first column (in bold) indicates the Genexpress Index number (GENX). Accession numbers correspond either to Genexpress sequences (normal typing) or sequences from other groups (accession numbers preceded by \#) present in GenBank. The different columns for eSTS markers indicate the Genexpress Index number (col. 1), GDB D-number (col. 2), sequences of forward (col. 3) or reverse (col. 4) primers, and expected (col. 5) and observed (col. 6) sizes for the genomic PCR product. 
Downloaded from genome.cshlp.org on April 25, 2023 - Published by Cold Spring Harbor Laboratory Press

Appendix 1A: Known gene transcripts

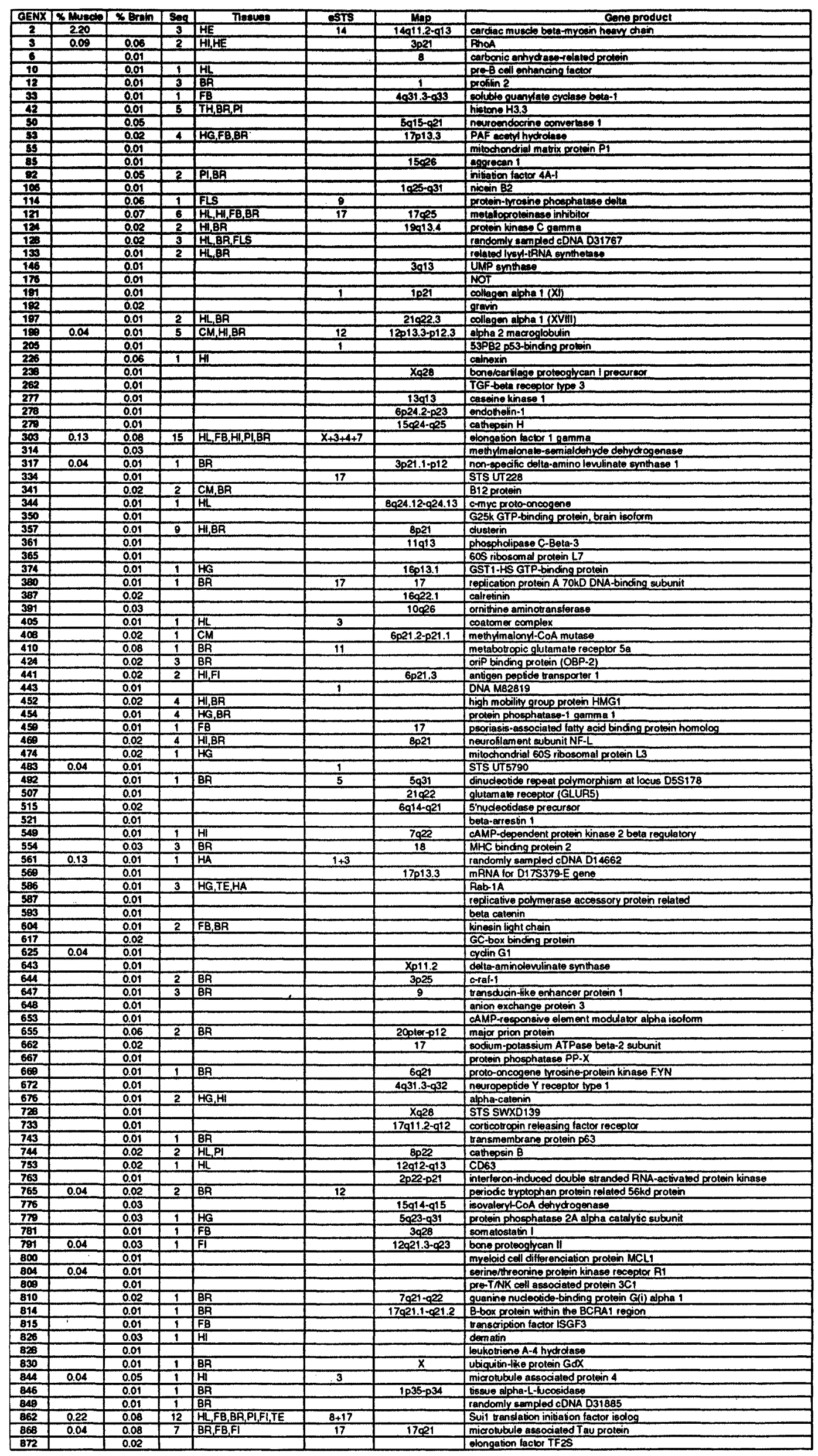


Appendix 1 Ro:knloaded from genome.csslp.org on April 25, 2023 - Published by Cold Spring Harbor Laboratory Press

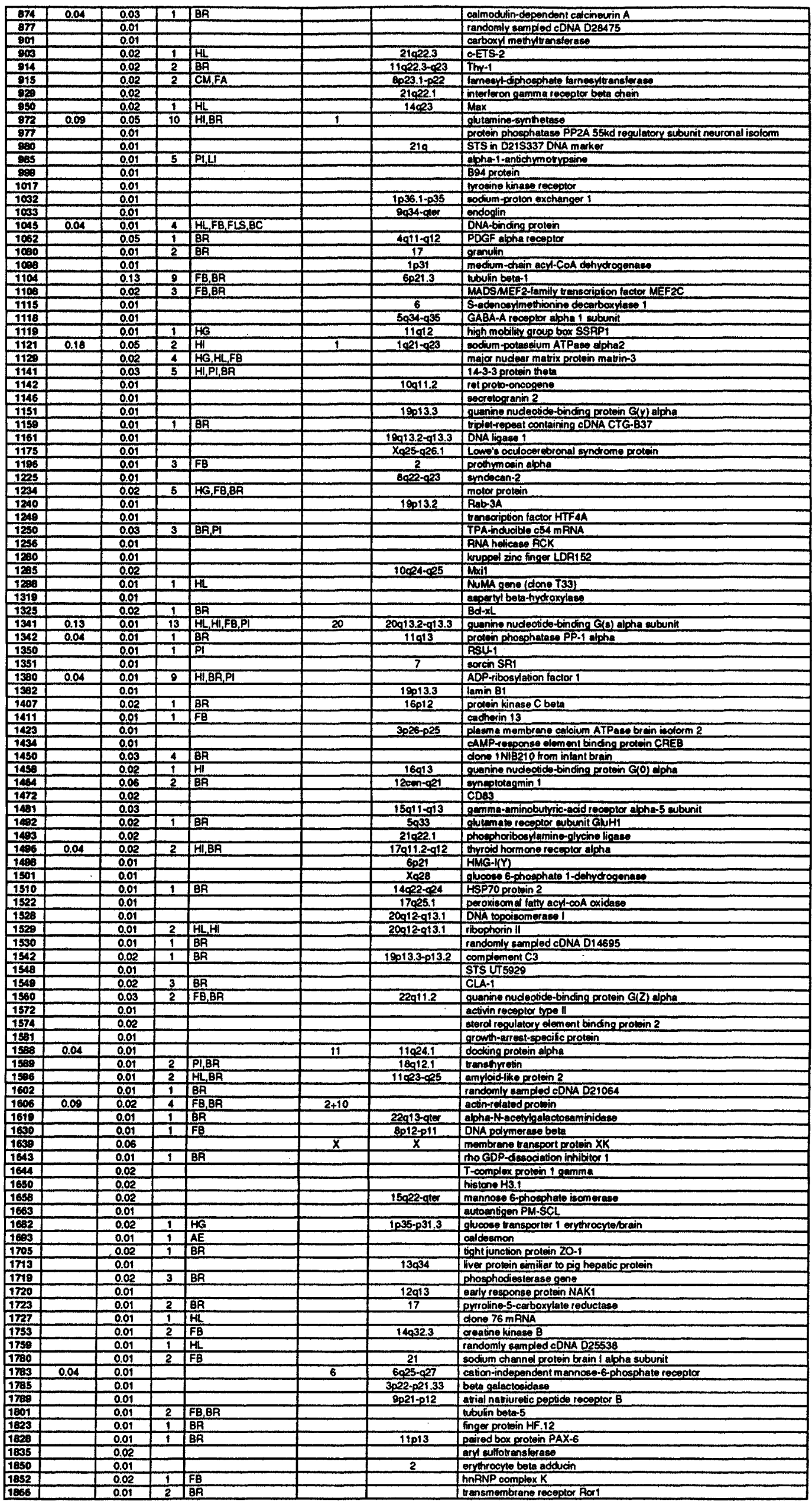


Downloaded from genome.cshlp.org on April 25, 2023 - Published by Cold Spring Harbor Laboratory Press Appendix 1A: Known gene transcripts (continued)

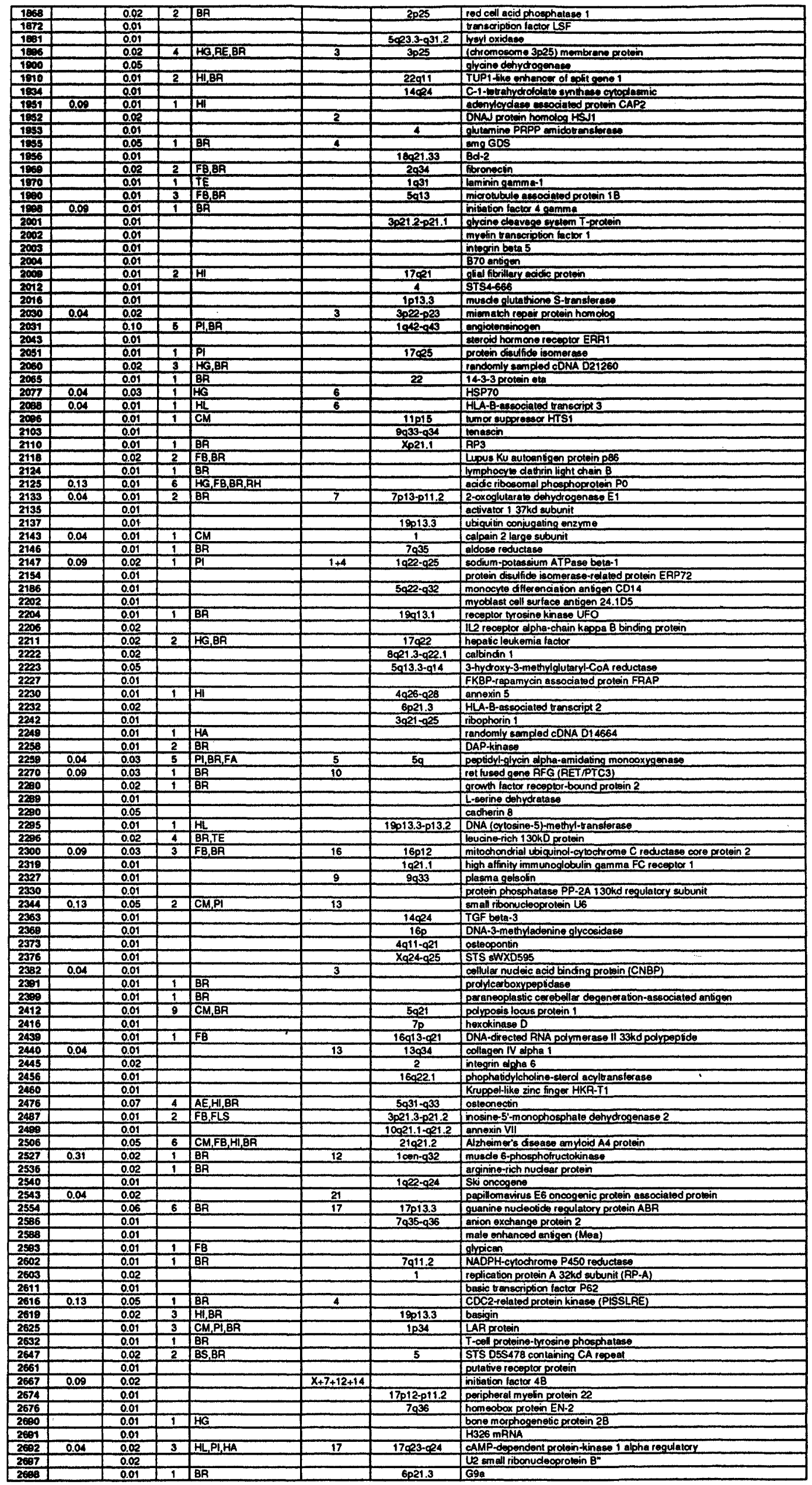




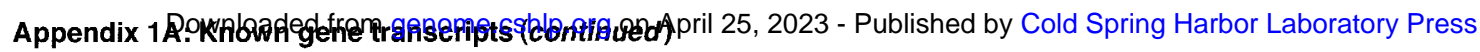

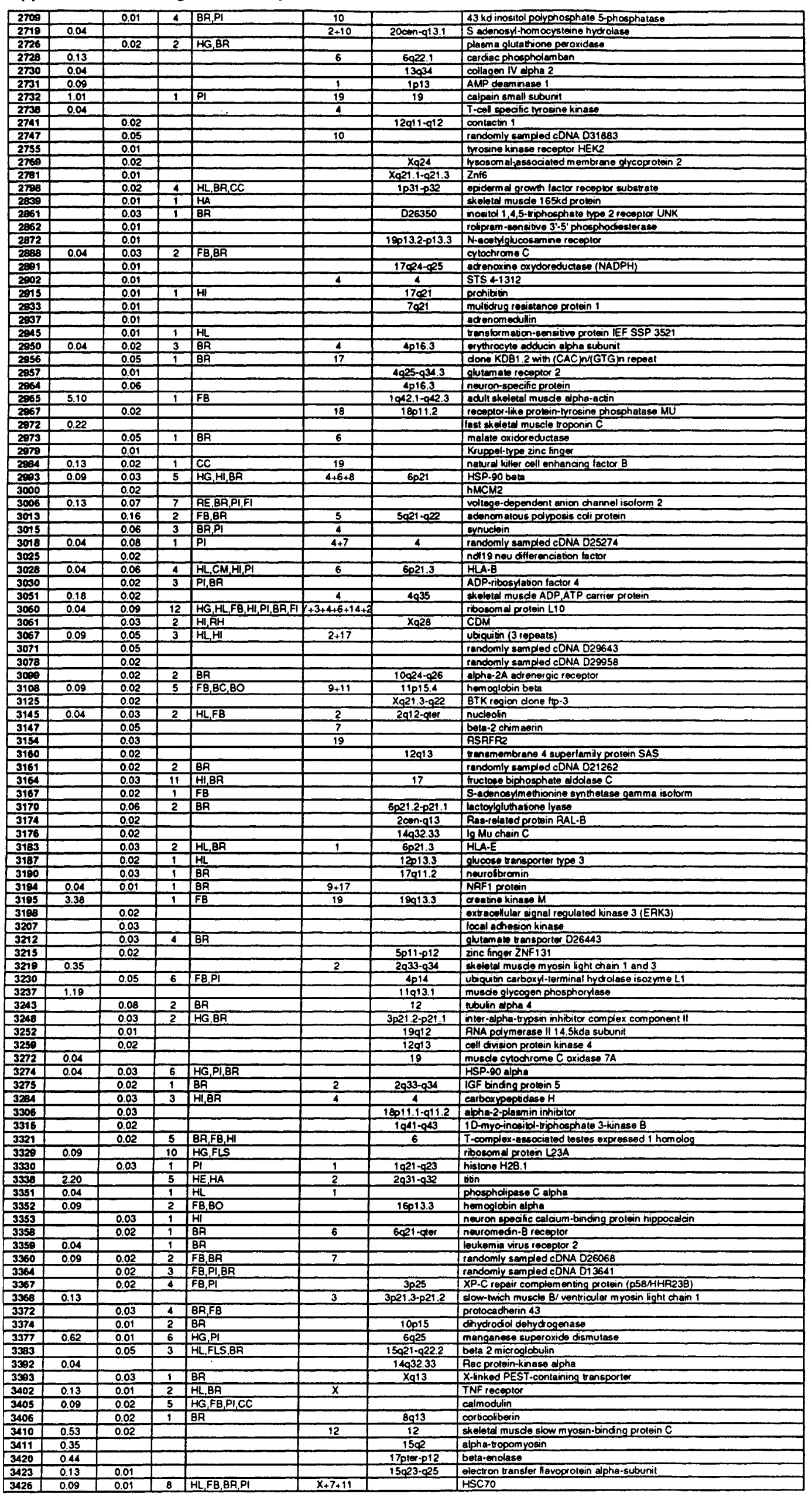




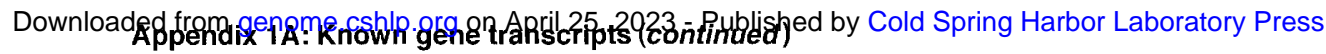

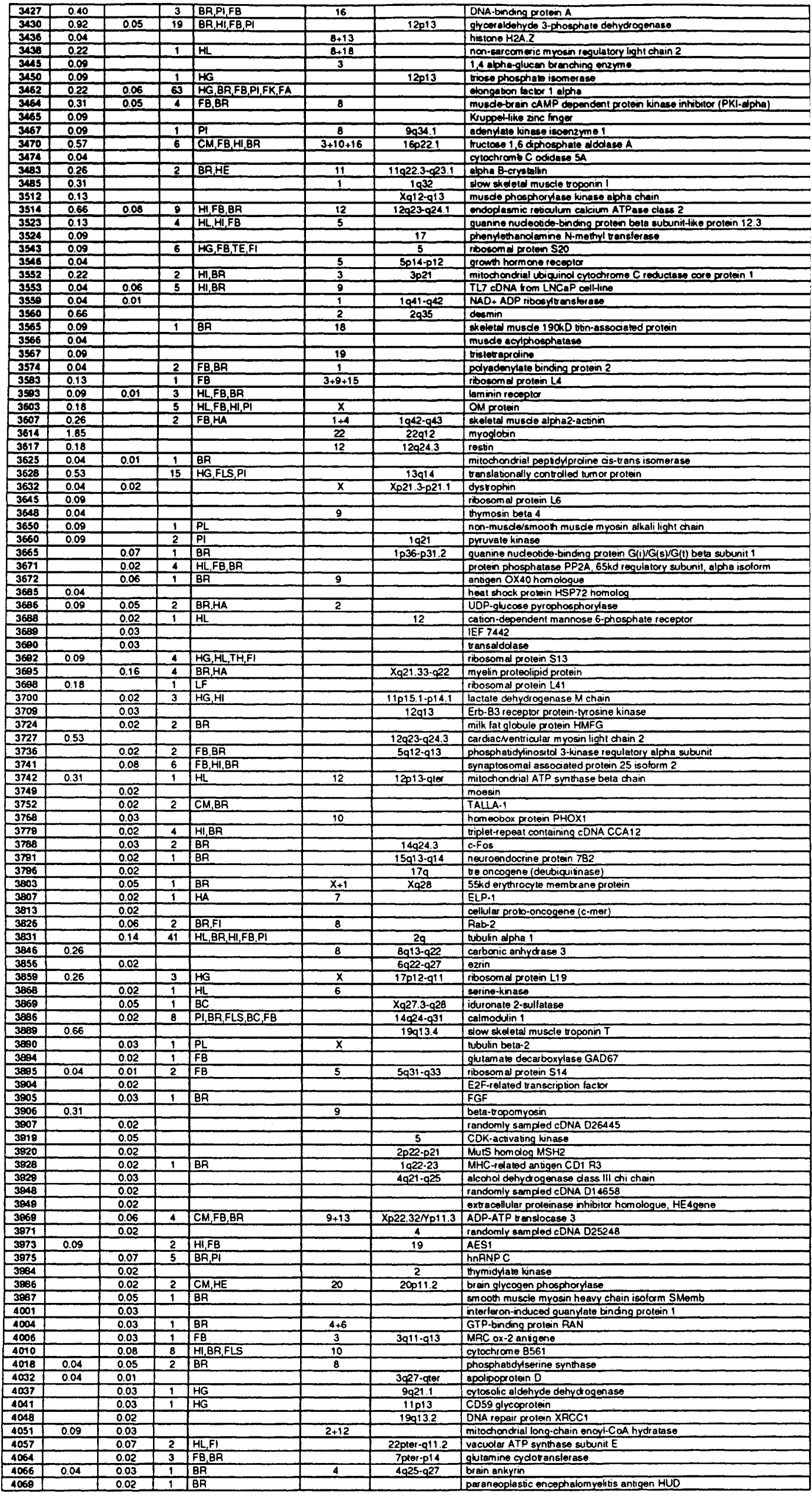


Downloaded from genome.cshlp.org on April 25, 2023 - Published by Cold Spring Harbor Laboratory Press

Downloaded from genome.cshlp.org on
Appendix 1A: Known gene transcripts (continued)

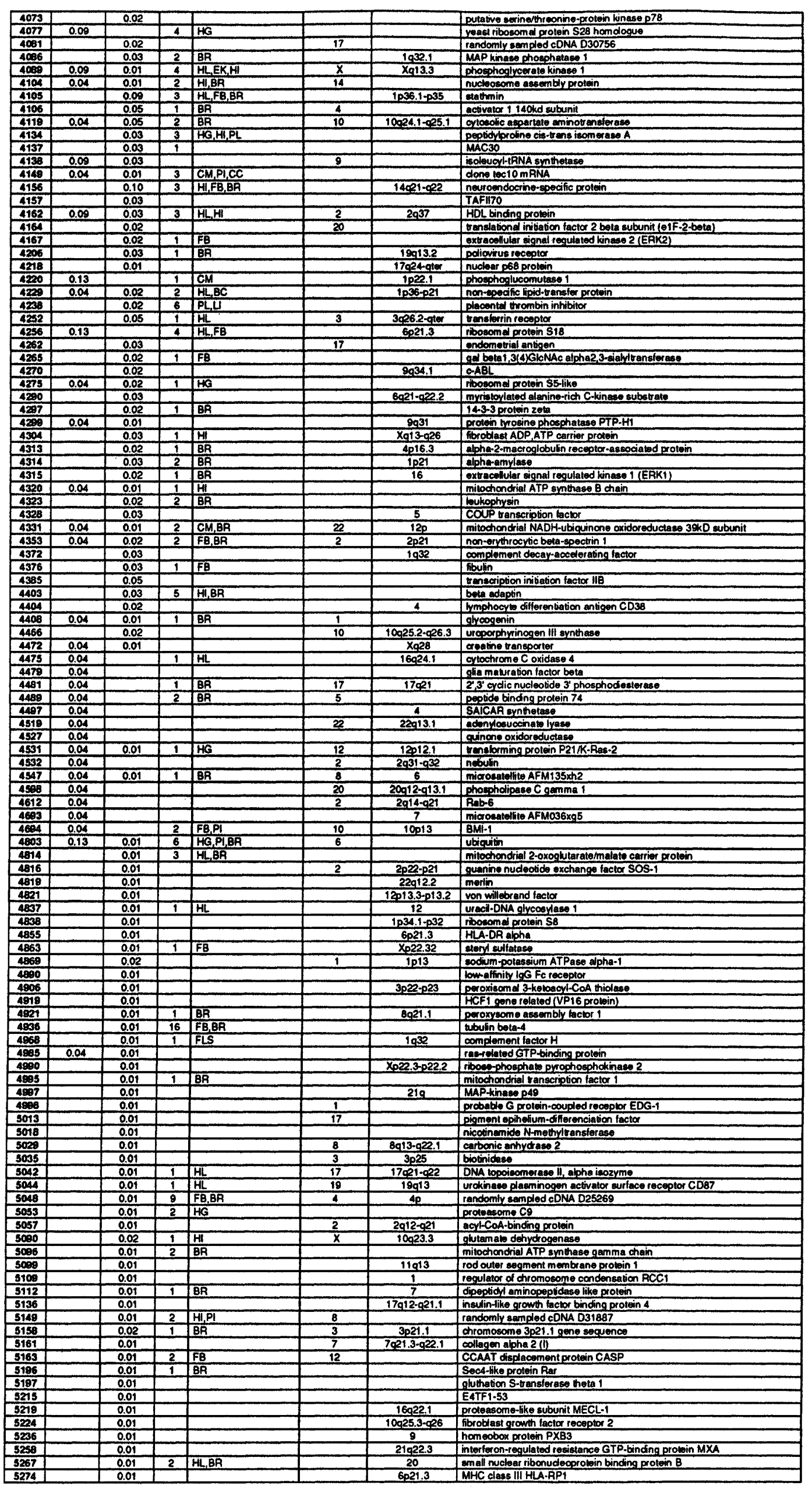


Downloaded from genome.cshlp.org on April 25, 2023 - Published by Cold Spring Harbor Laboratory Press

Appendix 1A: Known gene transcripts (continued)

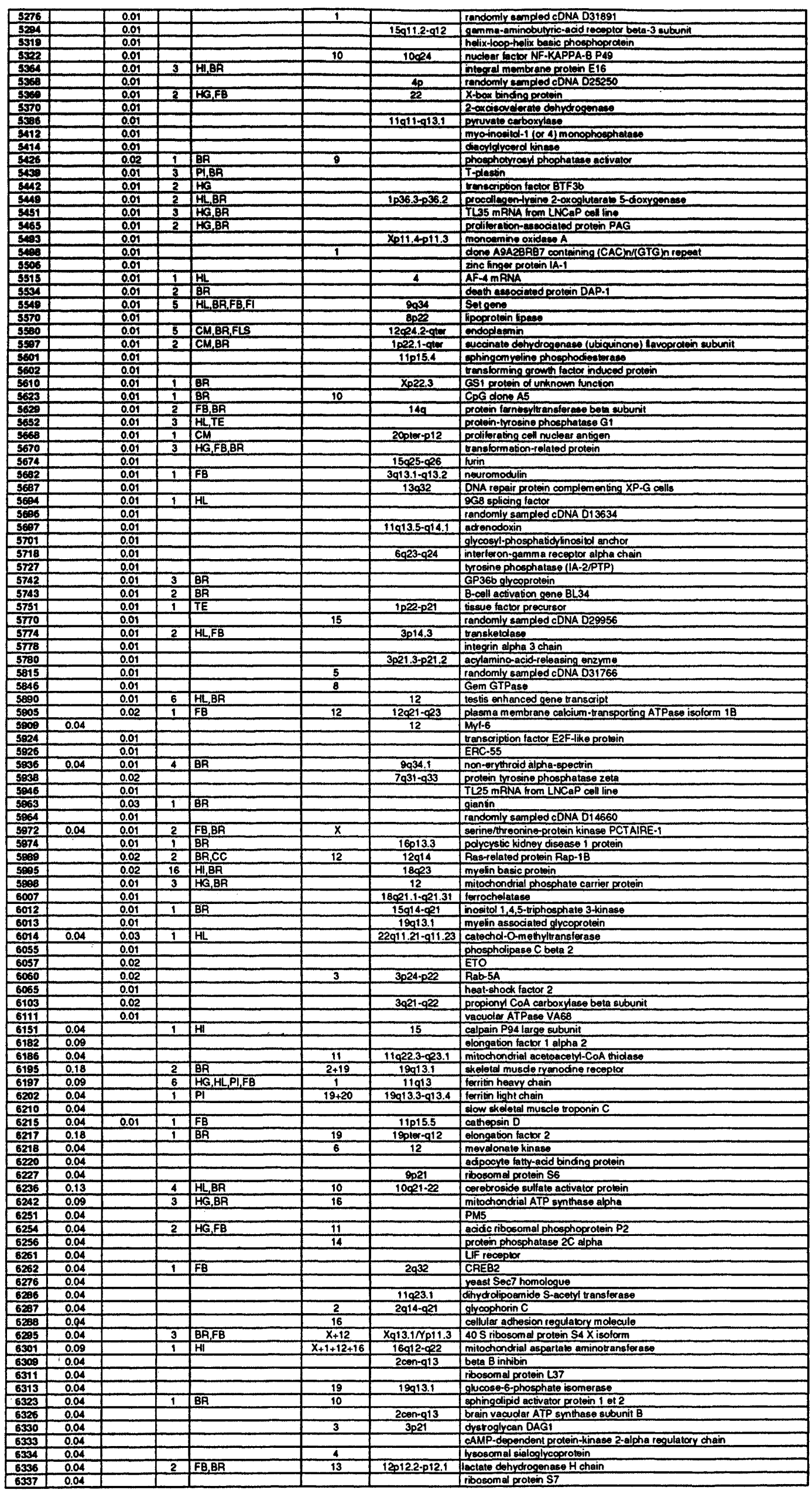


HOULGATTE ET AL.

Appendix 1A: Known gene transcripts (continued)

\begin{tabular}{|c|c|c|c|c|c|c|c|}
\hline 6364 & 0.04 & & & & 9 & 1011-ger & microsomal opoxide hydotase \\
\hline 6368 & 0.04 & & 2 & HL,FI & & & hnRNP homolog \\
\hline 6573 & 0.04 & & & & $3+9$ & & foosomed roloin L Lo (Yoasl APL 30 homolog) \\
\hline 6077 & 0.04 & 0.02 & 2 & HLFB & & $3022-925$ & podyadenylato binding proloin \\
\hline 6378 & 0.04 & & 1 & TE & $5+6$ & $\frac{1025-027}{6027}$ & T-complex protein 1 alphs subunit \\
\hline 8379 & 0.04 & & 1 & $F$ & $\frac{5}{5}$ & $5023-031$ & ubiguitin con uggating enzymo $E 2-17 \mathrm{kD}$ \\
\hline 6539 & 0.04 & & & & & $\frac{1}{6}$ & GMP reductase \\
\hline 6506 & 0.00 & 0.03 & & & 6 & 6021.3 & HLA-A \\
\hline 650 & 0.04 & & & & 17 & 170 ter-p11 & sketetel mued obota-myosin hoow chain \\
\hline 6403 & 0.04 & & 3 & BR,FLS & & & ribosomal protein $\$ 34$ \\
\hline 6411 & 0.04 & & & & & 15 & peptidybrotine cis-trens isomerase B \\
\hline 6412 & 0.04 & & 2 & FB,PI & & & Y-box binding protein \\
\hline 6410 & 0.04 & & & & & 7922 & acobychoinester ase \\
\hline 6437 & 0.04 & & & & & 6021.3 & HLA.C \\
\hline 648 & 0.04 & & & & & $6 \mathrm{p} 21.3$ & HLA-DR beta \\
\hline 6457 & 0.00 & & & & & & atrcogen debrenching enzyme \\
\hline 6458 & 0.04 & & & & $\bar{x}$ & & ovarien granulose coll $13.0 \mathrm{KD}$ probin HGA74 \\
\hline 6463 & 0.04 & & & & 20 & $1036-022$ & epermidine smthase \\
\hline 6480 & 0.04 & & & & 4 & 4 & long chein bitr acid CoA tigase \\
\hline 6481 & 0.04 & & & & & $14911.2-913$ & cardiac atpha-myosin heavy choin \\
\hline 6502 & 0.04 & & & & 7 & $7 p+2$ & EGF reciptor \\
\hline 65003 & 0.04 & & 6 & BR,PI,BO & $11+16$ & & putative ribosomal protein $\mathrm{L} 13$ \\
\hline 6504 & 0.04 & & & & 1 & & milochondrial ubiquinol-eytoohrome C reductace $11 \mathrm{kD}$ prolein \\
\hline 6510 & 0.04 & & & & & & ribosomal protein 123 \\
\hline 6513 & 0.04 & & & & & $\overline{x p 22.3}$ & putetive achesion molocule \\
\hline 6514 & 0.04 & & & & 22 & $22,12.1 .913 .2$ & metallogrotcineses 3 inhibitor \\
\hline 6517 & 0.04 & & & & 20 & & relincic acid-inducible transglutaminase homologue \\
\hline 6593 & 0.04 & & 2 & HL,HA & $\frac{5}{5}$ & 11023.3 & riboesome protein $\mathbf{S} 25$ \\
\hline 6524 & 0.09 & & & & 5 & $\frac{5}{5}$ & sarcomeric mitochondial ereatin ol kinase \\
\hline 8536 & 0.04 & & & & & 18913.1 & Cy tochrom $C$ axidese 68 \\
\hline 6533 & 0.04 & & & & & $3025.1-025.2$ & neprilysin \\
\hline 65336 & 0.04 & & & & 1 & 1031 & glucose transporter type 5 \\
\hline 6538 & 0.04 & & & & & 11015.5 & transiorming protein P21/H+Reg-1 \\
\hline 65330 & 0.04 & & & & 17 & 17013.1 & phoephoprotein p53 \\
\hline 6591 & 0.04 & & & & & & randornly sampled cDNA D13642 \\
\hline 6549 & 0.04 & & 1 & HL & & 10913.3 & dectron transier flavogrolein bele-subunit \\
\hline 6546 & 0.04 & & 1 & HI & $\overline{x+15}$ & $15024-025$ & prruvato kinase M2 \\
\hline 6547 & 0.04 & & & & $\frac{1+12}{1+12}$ & & phoephatidy-ethanolemin s binding prowin \\
\hline 6567 & 0.04 & & $T$ & Hiा & & $11 p 13$ & calateres \\
\hline 6593 & 0.04 & & & & & & ORF M68B64 \\
\hline 6508 & 0.04 & & & & 17 & & prolvasome delta chain \\
\hline 6500 & 0.04 & & & & & 5931.933 & HLA-DR antigens essocialod invariant chain \\
\hline 6606 & 0.04 & & & & & & calpain inhibitor \\
\hline$\frac{6611}{6611}$ & 0.04 & & & & 4 & a & STS 4.248 \\
\hline 6620 & 0.04 & & & & 20 & 20 & major centromero aubantigen $B$ \\
\hline 6621 & 0.04 & & 6 & HG,FB,FLS & & & ribosom al prolein S3 homolog \\
\hline 6637 & 0.04 & & 1 & BA & & $\overline{12913}$ & hnRNPAt \\
\hline 8630 & 0.04 & & & & & & hnRNPA2 \\
\hline$\frac{0.053}{6653}$ & & 0.01 & & & & & nuclear respiratory factor-1 \\
\hline 8682 & & 0.04 & & & & & randomly sempled cDNA D13643 \\
\hline$\frac{0683}{663}$ & & 0.01 & & & & & $\frac{102}{10-2}$ \\
\hline 6601 & & 0.01 & & & & & P-selectin ligand \\
\hline 6609 & & 0.09 & 2 & BR & & & randomly sampled eDNA D25217 \\
\hline 6709 & & 0.01 & & & 7 & $7013-012$ & GF binding probein 3 \\
\hline 6711 & & 0.01 & & & $8+10$ & $9622.1-022.2$ & catheosin $L$ \\
\hline 6718 & & 0.01 & & & & 60213 & complement C4 \\
\hline 6733 & & 0.01 & $T$ & BR & 4 & 17925 & solicing lactor SC35 \\
\hline 6747 & & 0.01 & & & & & smooth muecle proven 22-alphe \\
\hline 6748 & & 0.01 & & & $12+17$ & & protein trosing kinase \\
\hline 6752 & & 0.01 & & & & & erine/throoning-prolein kinace receptor R5 \\
\hline 6759 & & 0.01 & & & & & coalomer beta' wubunit \\
\hline 6781 & & 0.01 & & & & & deoxycytidylale deerninase \\
\hline 6787 & & 0.01 & & & & 2037.3 & collagen VI Etpha 3 \\
\hline 6823 & & 0.04 & $T$ & HI & & & DNAJ protein homolog 1 \\
\hline 6BA1 & & 0.01 & & & & 10024 & urokinase-type plasminogen activator \\
\hline 6845 & & 0.01 & & & & $6 \mathrm{p} 21.3$ & reincic acid receplor RXR-beta \\
\hline 6899 & & 0.01 & & & 9 & & glutamate transporter U08989 \\
\hline 66983 & & 0.01 & & & & & vacuoler ATP synthase subunit C \\
\hline 6801 & 0.04 & & 3 & HELLPI & & 17p11-ater & cytoskeletal gamme-acin \\
\hline 6803 & 0.04 & 0.03 & 18 & $\mathrm{HI}, \mathrm{FB}, \mathrm{BR}, \mathrm{PI}, \mathrm{PL}$ & & $7 p 15-p 12$ & crtoplasmic acin 1 (beta) \\
\hline 6916 & & 0.05 & & & & & randomly sampled cDNA D 7793 \\
\hline
\end{tabular}


Appendix 1B: Homolog gene transcripts

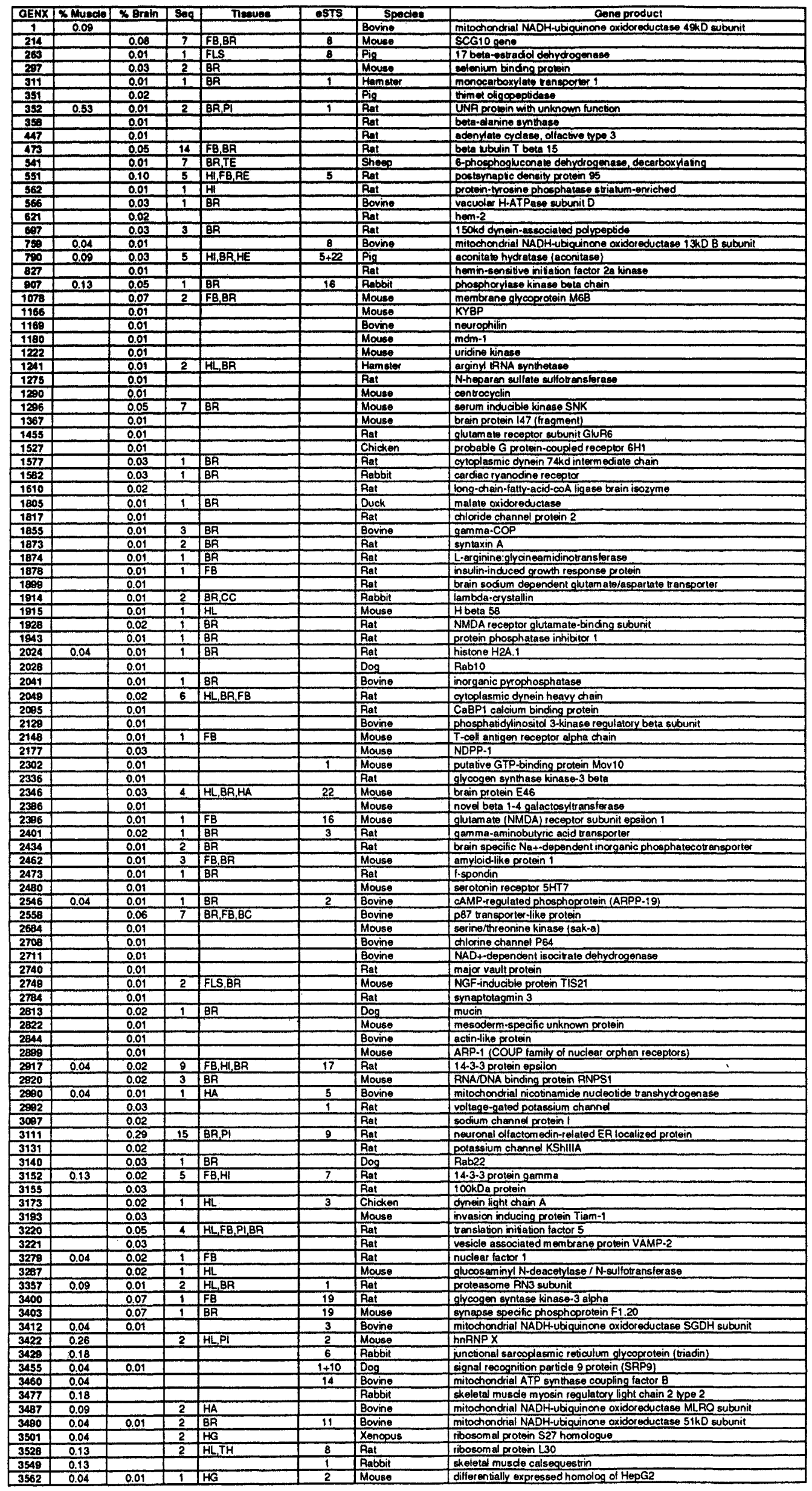


Appendix 1B: Homolog gene transcripts (continued)

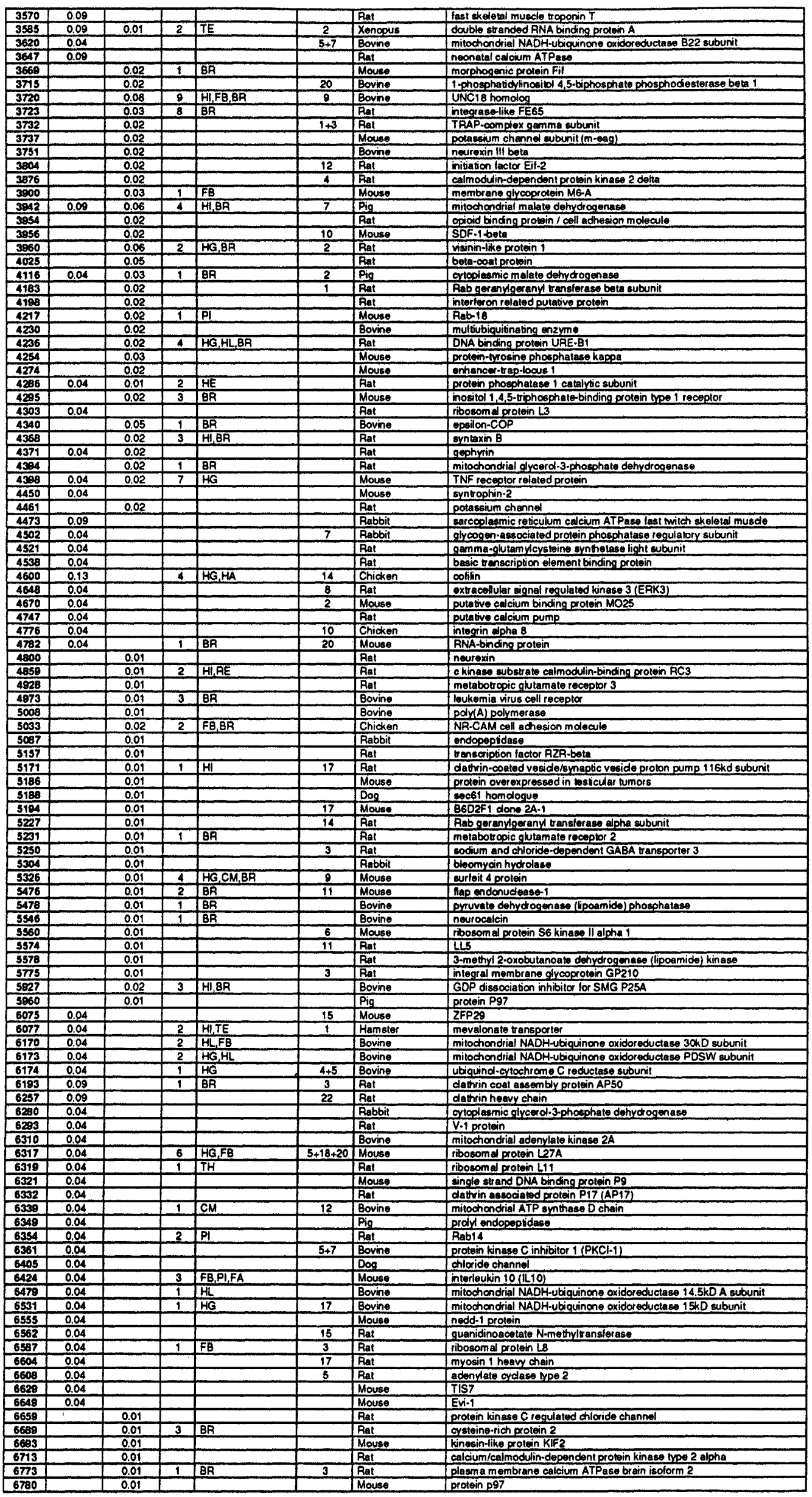




\section{Appendix 1C: Related gene transcripts}

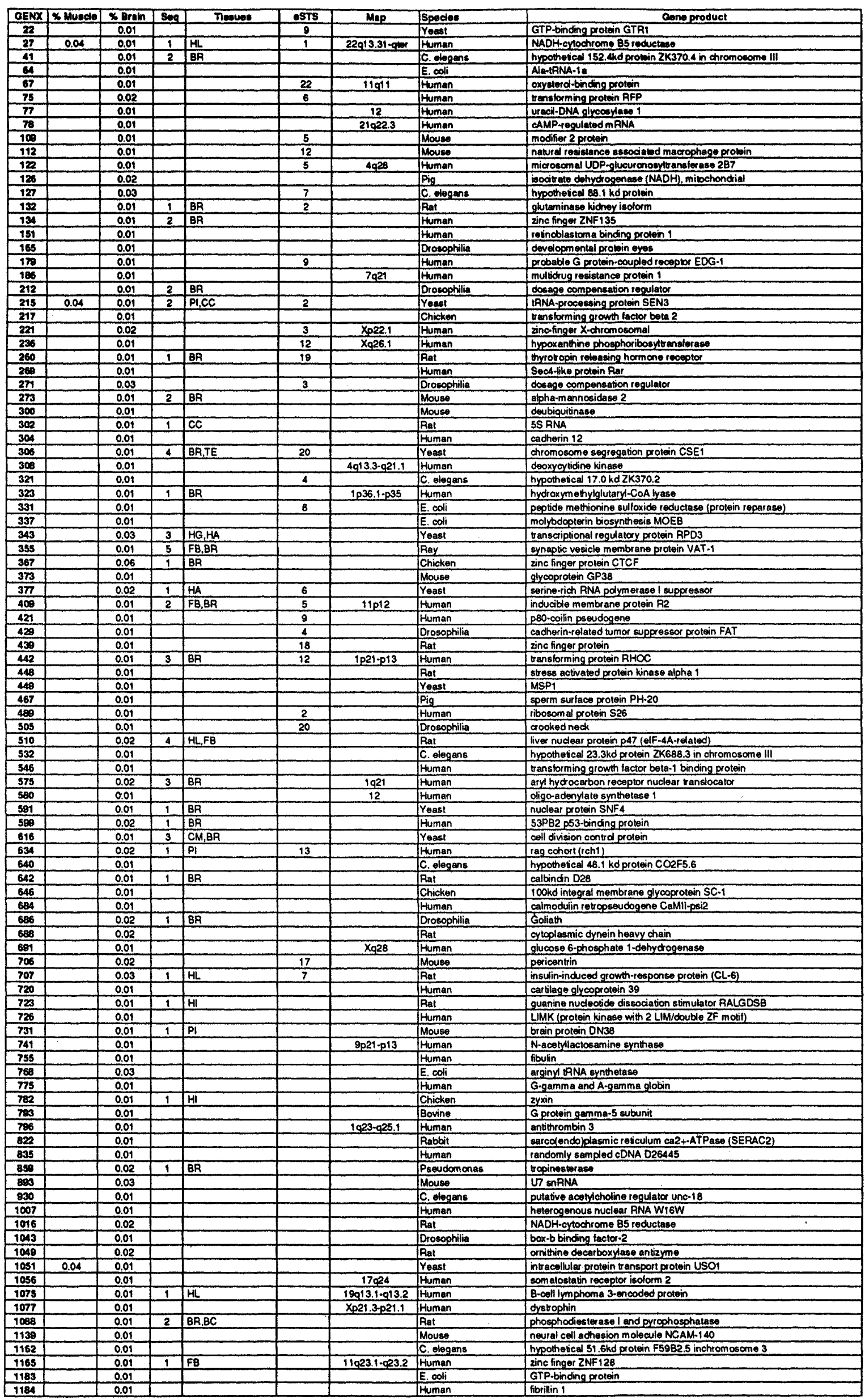


Downloaded from genome.cshlp.org on April 25, 2023 - Published by Cold Spring Harbor Laboratory Press Appendix 1C: Related gene transcripts (continued)

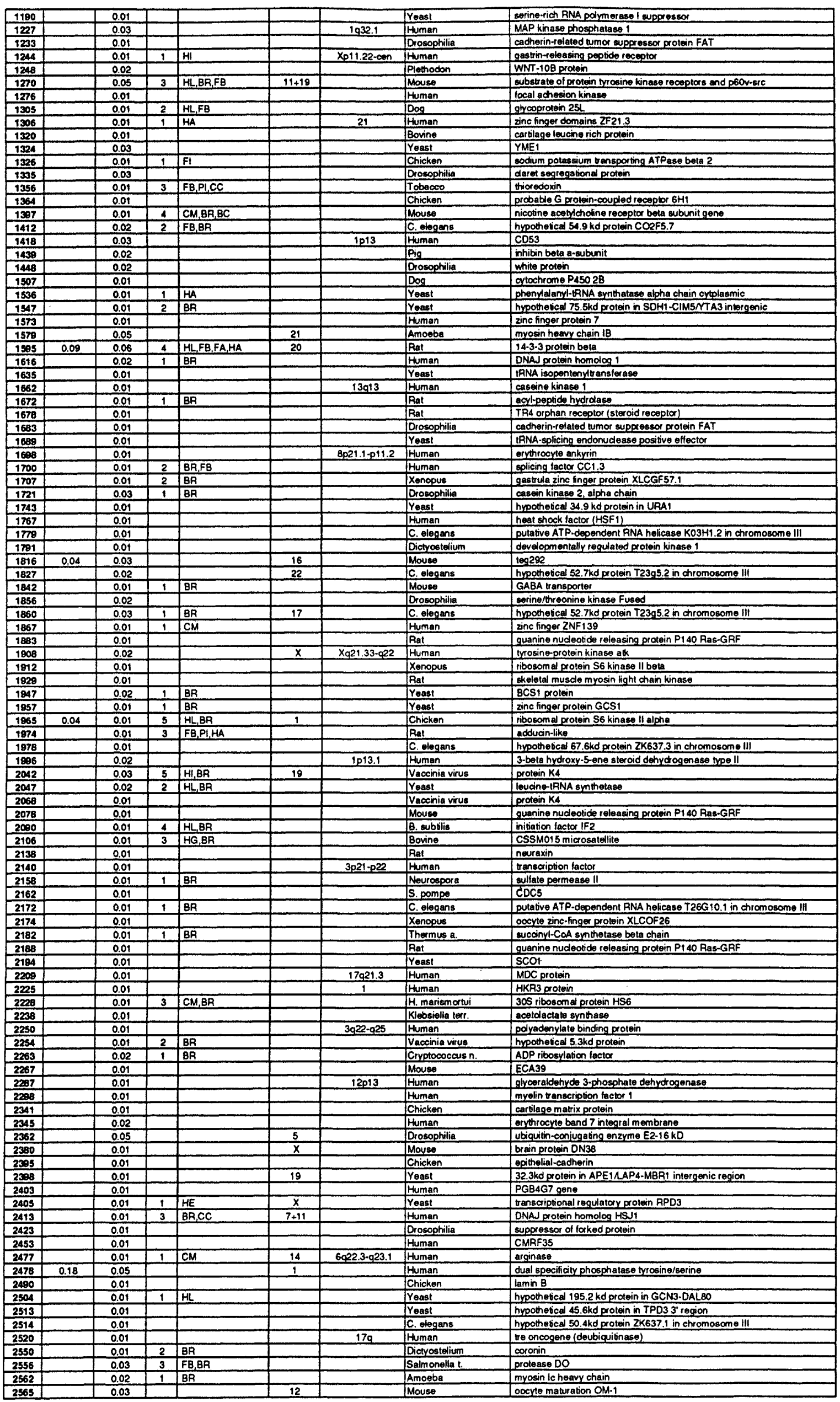


Downloaded from genome.cshlp.org on April 25, 2023 - Published by Cold Spring Harbor Laboratory Press Appendix 1C: Related gene transcripts (continued)

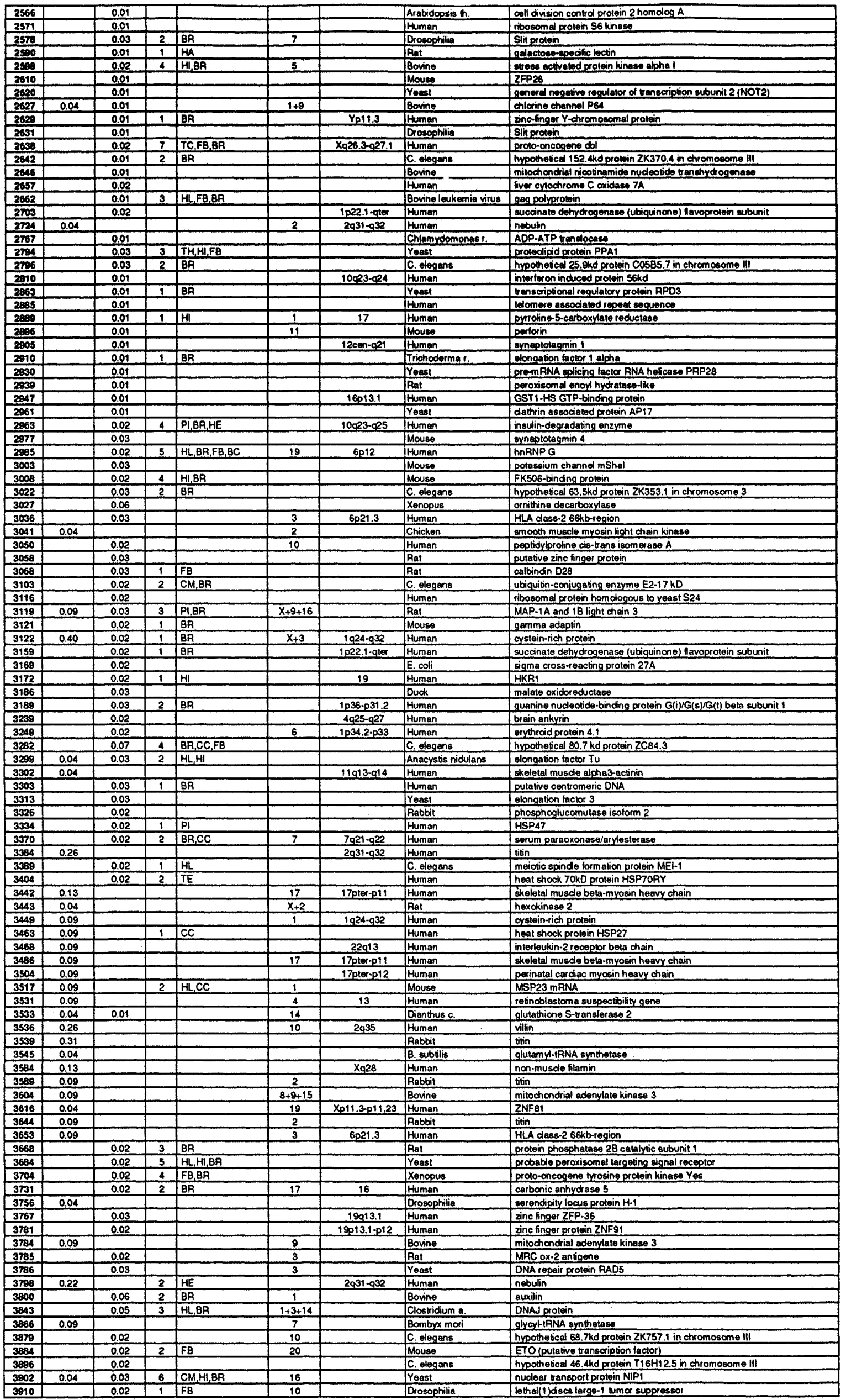




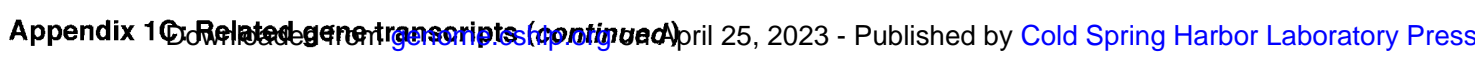

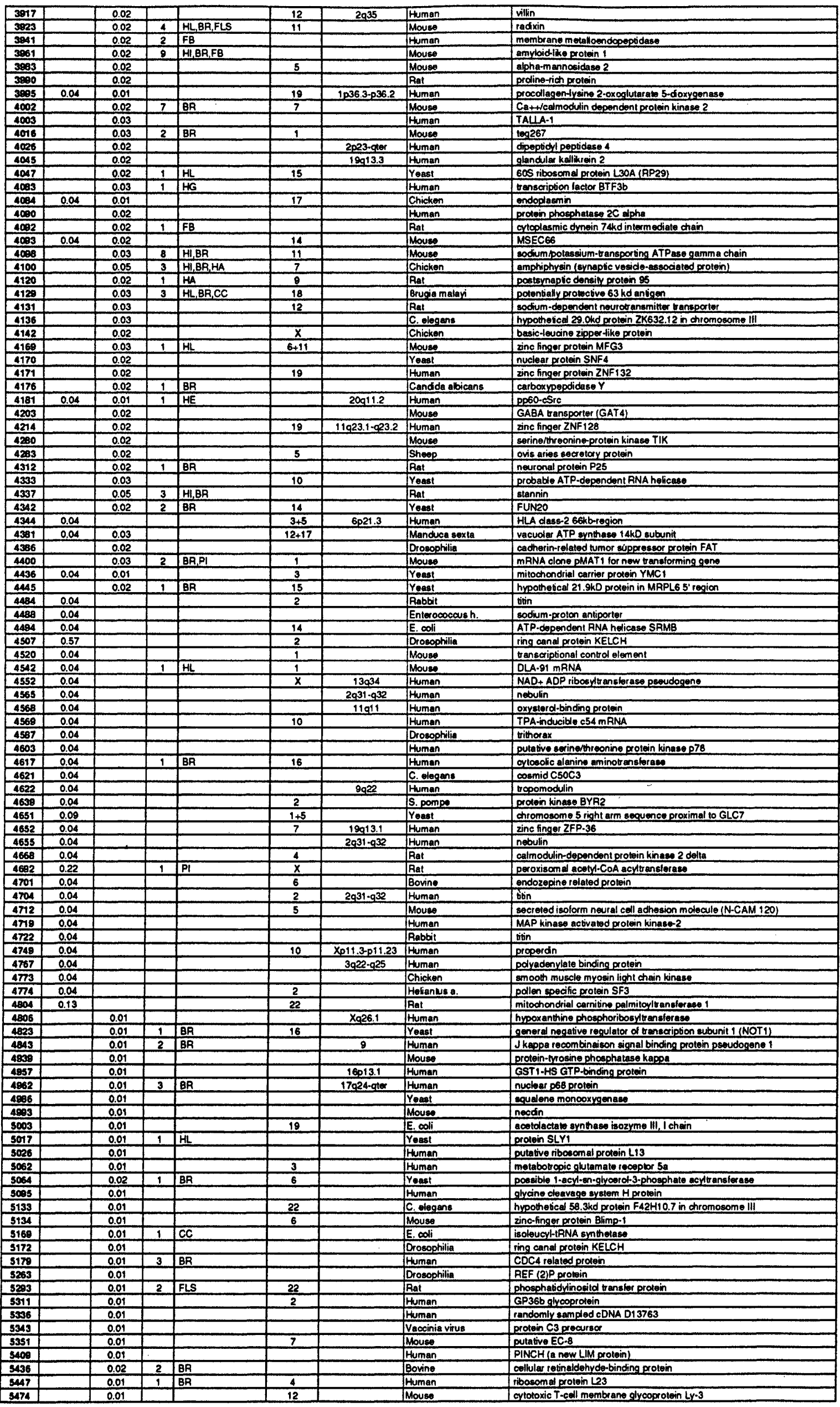


GENEXPRESS INDEX

Appendix 1C: Related gene transcripts (continued)

\begin{tabular}{|c|c|c|c|c|c|c|}
\hline 3400 & & 0.01 & & & & \\
\hline 3500 & & 0.01 & 2 & HL,PI & 8 & \\
\hline 3507 & & 0.01 & & & 20 & \\
\hline 3510 & & 0.01 & & & 16 & $16 p 13.3$ \\
\hline 3550 & & 0.01 & & & & \\
\hline 3576 & & 0.01 & & & 17 & \\
\hline 3600 & & 0.01 & & & 2 & \\
\hline 5640 & & 0.01 & & & 16 & \\
\hline 3664 & & 0.01 & & & & $4025-927$ \\
\hline 3609 & & 0.01 & 5 & $\mathrm{HG}, \mathrm{BR}, \mathrm{CC}$ & & \\
\hline 5706 & & 0.01 & & & & \\
\hline 5774 & & 0.01 & & & & \\
\hline 5777 & & 0.01 & & & & \\
\hline 5722 & & 0.01 & & & & \\
\hline 5723 & & 0.01 & & & & \\
\hline 5724 & & 0.01 & 2 & BR,FB & 17 & \\
\hline 5811 & & 0.01 & & & & $3 p 21-p 22$ \\
\hline $\sin 16$ & & 0.01 & & & 17 & \\
\hline 5831 & & 0.09 & & & 1 & 9934.1 \\
\hline 5639 & & 0.01 & & & & 1032.1 \\
\hline S2947 & & 0.01 & 1 & BR & & \\
\hline 5030 & & 0.01 & 3 & ER & & \\
\hline 5870 & & 0.01 & & & 19 & 11023 \\
\hline 5875 & & 0.01 & & & & \\
\hline 5832 & & 0.01 & 1 & BA & & \\
\hline 5029 & 0.09 & & & & 2 & \\
\hline 6078 & 0.04 & & & & 6 & \\
\hline 6034 & 0.04 & & & & $x$ & $x_{011.4-p 11.3}$ \\
\hline 6001 & 0.04 & & & & 12 & \\
\hline 6005 & 0.04 & & & & 19 & \\
\hline 6123 & & 0.01 & & & $x$ & \\
\hline 6153 & 0.04 & & & & 3 & $4 p 16.3$ \\
\hline 6150 & 0.04 & & & & 10 & \\
\hline 6182 & 0.04 & & & & & 1031 \\
\hline 6199 & 0.04 & & & & & \\
\hline 6209 & 0.04 & & & & 17 & \\
\hline 6237 & 0.04 & & 1 & $P 1$ & & \\
\hline 6240 & 0.04 & & & & & \\
\hline 6282 & 0.04 & & & & 22 & \\
\hline 62309 & 0.04 & & & & & 17 pler-p12 \\
\hline 6335 & 0.04 & & & & & \\
\hline 6370 & 0.04 & & 1 & $\mathrm{HL}$ & 19 & \\
\hline 6374 & 0.04 & & & & & \\
\hline 6374 & 0.04 & & & & & \\
\hline 6375 & 0.04 & & 1 & $\mathrm{PI}$ & & \\
\hline 6383 & 0.04 & & & & & 9922 \\
\hline 6391 & 0.04 & & & & & $2931-932$ \\
\hline 6404 & 0.04 & & 1 & $B A$ & & \\
\hline 6414 & 0.04 & & 1 & BR & & \\
\hline 6417 & 0.04 & & & & & 17pter-p11 \\
\hline 6428 & 0.04 & & & & & \\
\hline 6441 & 0.04 & & & & 17 & $17 p t e x-p 12$ \\
\hline 6453 & 0.04 & & & & & \\
\hline 6472 & 0.04 & & & & & \\
\hline 6478 & 0.04 & & & & 20 & \\
\hline 6482 & & 0.02 & & & & \\
\hline 6496 & 0.04 & & & & 1 & \\
\hline 6511 & 0.04 & & & & 3 & \\
\hline 6543 & 0.04 & & & & & \\
\hline 6545 & 0.04 & & & & 3 & 9922 \\
\hline 6550 & 0.04 & & & & & \\
\hline 6551 & 0.04 & & & & & \\
\hline 6557 & 0.04 & & & & 12 & \\
\hline 6558 & 0.04 & & & & & \\
\hline 6573 & 0.09 & 0.01 & 1 & BR & 8 & \\
\hline 6577 & 0.04 & & & & $14+16$ & $3022 \cdot 025$ \\
\hline 6593 & 0.04 & & & & 2 & \\
\hline 6586 & 0.04 & & & & & \\
\hline 6591 & 0.04 & & & & 17 & \\
\hline 6592 & 0.04 & & & & 1 & $22 q^{13} .31-9 \operatorname{tar}$ \\
\hline 6618 & 0.04 & & & & 9 & \\
\hline 6630 & 0.04 & & & & & \\
\hline 6633 & 0.04 & & & & 22 & 12 \\
\hline 6648 & 0.04 & & & & & \\
\hline 6668 & & 0.01 & & & & \\
\hline 6706 & & 0.01 & & & & \\
\hline 6739 & & 0.01 & & & & \\
\hline 6743 & & 0.01 & & & & 4 \\
\hline 6760 & & 0.01 & & & & \\
\hline 6771 & & 0.01 & & & 3 & \\
\hline 6776 & & 0.01 & & & & \\
\hline 679 & & 0.01 & & & & \\
\hline 6782 & & 0.01 & & & & \\
\hline 6000 & & 0.01 & & & & 21022.3 \\
\hline 6614 & & 0.01 & & & 4 & \\
\hline 6824 & & 0.01 & 1 & HA & 12 & \\
\hline 6833 & & 0.01 & & & 19 & $18913.2-013.4$ \\
\hline 6849 & & 0.01 & & & & \\
\hline 6060 & & 0.01 & & & 19 & $11023.1-023.2$ \\
\hline 6870 & & 0.01 & & & & \\
\hline 6871 & & 0.01 & & & 19 & $4912-921$ \\
\hline 6876 & & 0.01 & 9 & HA & & \\
\hline
\end{tabular}


HOULGATTE ET AL.

Appendix 1D: Unknown gene transcripts (partial)
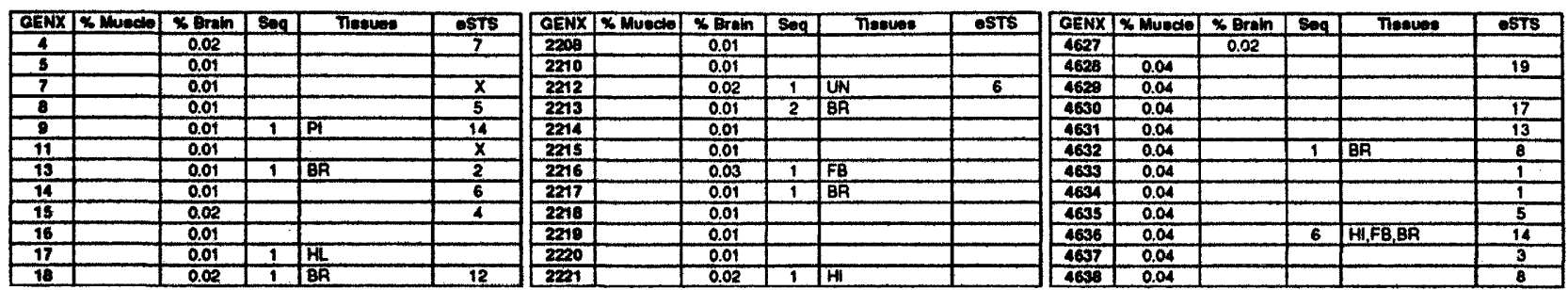

Appendix 1E: New gene transcripts in known regions

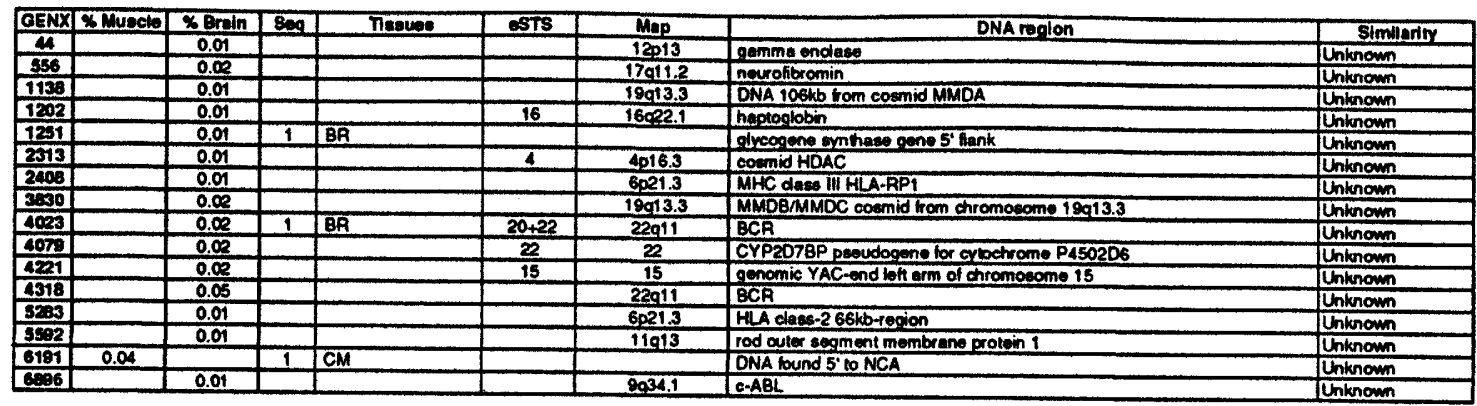

Appendix 1F: Overlapping gene transcripts

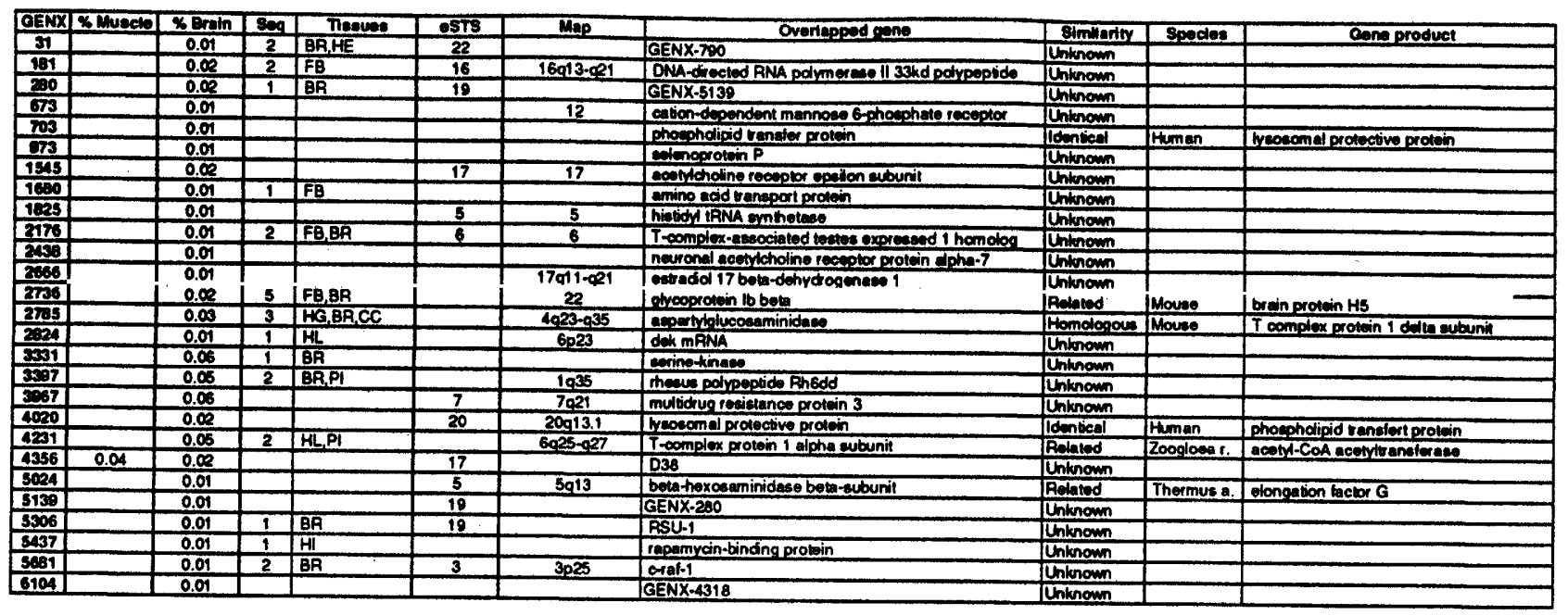

Appendix 2A: eSTS markers (partial)

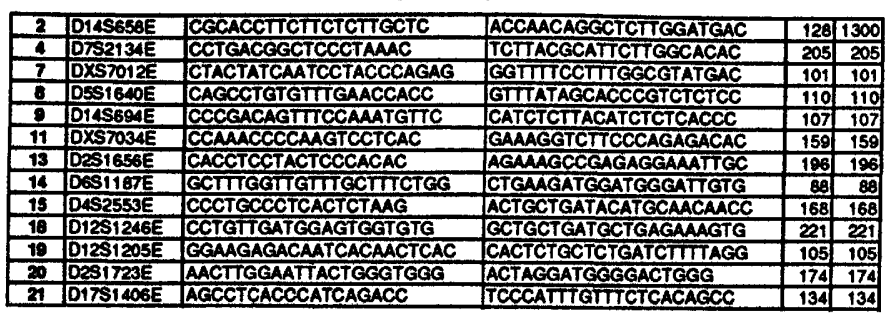

Appendix 2B: Accession number cross-index (partial)

\begin{tabular}{|c|c|c|c|c|c|}
\hline & & & & & \\
\hline & & 516 & & F00990 & F01167 \\
\hline 2 & 17415 & 21830 & 21832 & & \\
\hline 3 & & & & F00705 & \\
\hline 3 & 26696 & F06716 & F08458 & & IZ17832 \\
\hline 4 & F01528 & 239764 & F05275 & 243704 & \\
\hline & 239362 & $\mathbf{2 4 3 2 9 0}$ & & & \\
\hline 6 & 239364 & F06437 & & & \\
\hline 7 & 239365 & 243292 & & & \\
\hline$\therefore$ & Z39368 & 2443293 & & & \\
\hline- & 39370 & 243295 & $=$ & & \\
\hline 10 & F02728 & Fo6443 & 1020842 & & \\
\hline
\end{tabular}

\begin{tabular}{|c|c|c|c|c|c|}
\hline & & & & & \\
\hline 2307 & & & 1503897 & & \\
\hline 2308 & 241278 & 245590 & & & \\
\hline 2308 & 241230 & 245591 & & & \\
\hline 2310 & 241281 & F08269 & & & \\
\hline 2311 & 245594 & & & & \\
\hline 2312 & F01467 & F02587 & F02676 & 240181 & 241950 \\
\hline 2312 & F06297 & 243223 & 244209 & 7103617 & OT17387 \\
\hline 2313 & 504500 & F08271 & & & \\
\hline 2314 & 241284 & Z45596 & & & \\
\hline 2316 & 239060 & $F 04503$ & 245597 & \#T08590 & \\
\hline $\begin{array}{l}2317 \\
\end{array}$ & 241285 & 245598 & & & \\
\hline
\end{tabular}




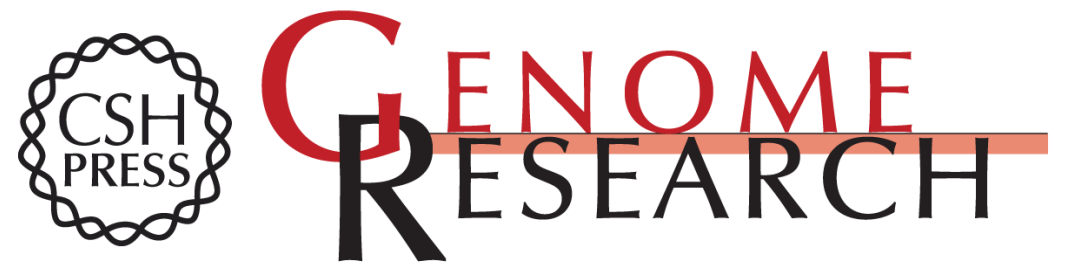

\section{The Genexpress Index: a resource for gene discovery and the genic map of the human genome.}

R Houlgatte, R Mariage-Samson, S Duprat, et al.

Genome Res. 1995 5: 272-304

Access the most recent version at doi:10.1101/gr.5.3.272

References This article cites 87 articles, 10 of which can be accessed free at:

http://genome.cshlp.org/content/5/3/272.full.html\#ref-list-1

\section{License}

Email Alerting Receive free email alerts when new articles cite this article - sign up in the box at the Service top right corner of the article or click here.

\section{Affordable, Accurate Sequencing.}

To subscribe to Genome Research go to:

https://genome.cshlp.org/subscriptions 